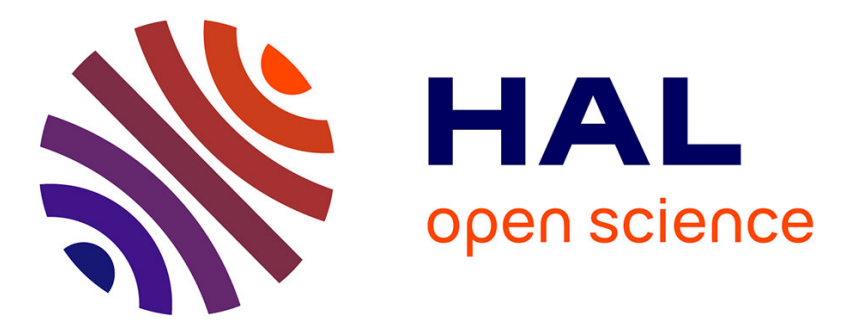

\title{
Bank Risk in Central and Eastern European Countries: Does Ownership Matter? \\ Ion Lapteacru
}

\section{To cite this version:}

Ion Lapteacru. Bank Risk in Central and Eastern European Countries: Does Ownership Matter?. 2016. hal-01338767

\section{HAL Id: hal-01338767 https://hal.science/hal-01338767}

Preprint submitted on 29 Jun 2016

HAL is a multi-disciplinary open access archive for the deposit and dissemination of scientific research documents, whether they are published or not. The documents may come from teaching and research institutions in France or abroad, or from public or private research centers.
L'archive ouverte pluridisciplinaire HAL, est destinée au dépôt et à la diffusion de documents scientifiques de niveau recherche, publiés ou non, émanant des établissements d'enseignement et de recherche français ou étrangers, des laboratoires publics ou privés. 


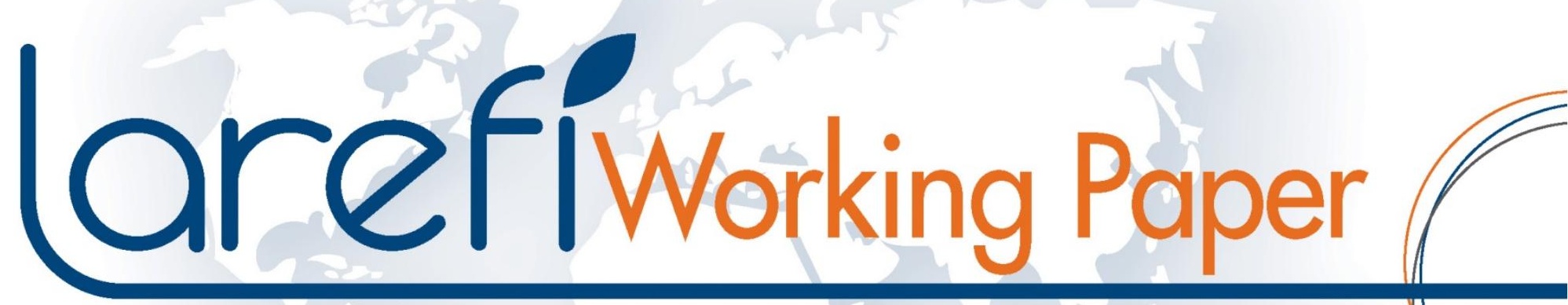

Laboratoire d'Analyse et de ReCherche en Économie et Finance InTERnationales

\section{Bank Risk in Central and Eastern European Countries: Does Ownership Matter?}

Ion Lapteacru

LAREFI Working Paper N²016-09

2016

http://lare-efi.u-bordeaux4.fr

LAREFI

Université Montesquieu-Bordeaux IV Bâtiment Recherche Economie $-1^{\text {er }}$ étage Avenue Léon Duguit - 33608 Pessac 


\section{AUTHORS}

Ion Lapteacru, LAREFI, Université Montesquieu Bordeaux IV

\section{NOTICES}

LAREFI Working Papers contain preliminary material and research results. They have been peer reviewed. They are circulated in order to stimulate discussion and critical comment; any opinions expressed are only those of the author(s).

Copyright LAREFI. All rights reserved. Sections of this material may be reproduced for personal and not-for-profit use without the express written permission of but with acknowledgment to LAREFI. To reproduce the material contained herein for profit or commercial use requires express written permission. To obtain permission, contact LAREFI at cyril.mesmer@u-bordeaux4.fr. 


\title{
Bank Risk in Central and Eastern European Countries: Does Ownership Matter?
}

\author{
Ion Lapteacru
}

Larefi, Department of Economics, University of Bordeaux, Avenue Léon Duguit, 33608 PESSAC, FRANCE, email: ion.lapteacru@u-bordeaux.fr, tel.: +33556842556, fax.: $+33556848534$

\begin{abstract}
Our main objectives are to estimate the risk of Central and Eastern European banks and determine its factors focussing on the role of ownership structures. We apply market-based risk measures and an improved Z-score and conclude that foreign and private banks are less risky than state-owned institutions. Moreover, a higher proportion of interbank deposits amplifies the risk of foreign banks and reduces that of public institutions. The effect of longterm funds is negative for state-owned banks with market-based measure, whereas it is positive with accounting-based measure. Another result is the negative impact of the concentration on interest-bearing activities on the risk of all banks regardless their ownership structure. Finally, the enforcement of the banking regulation reduces the risk of foreign banks and increases that of public institutions.
\end{abstract}

JEL classification: G21, P29

Keywords: Bank risk; Distance to Default; Z-score; ownership structures; Central and Eastern European economies. 


\section{Introduction}

Since the late 1980s and the early 1990s, Central and Eastern European (CEE) countries have implemented many reforms that have profoundly changed the organisation and structure not only of their economies but also of their banking systems. Many state-owned banks have been privatised and many other banks entered into these markets on the greenfield basis. The openness of these markets makes banks vulnerable to both domestic and external economic and financial turmoils. Several crisis episodes have influenced the structure of these markets, the ownership of banks and their investment behaviour and have highlighted the extent to which CEE banks are vulnerable. CEE markets have experienced many bank bankruptcies and changes in the ownership structures of surviving banks, and has led authorities to 'clean up' and stabilise their countries’ banks, essentially by enforcing banking regulation.

The interest of this paper is thus to investigate the risk of CEE banks - namely of new European Union (EU) member states because they share a system of common banking regulatory rules which makes them homogeneous from the banking regulation perspective and the impact of ownership structure on banks’ risk. In particular, we analyse whether stateowned, private and foreign banks have different risk profiles. We try to shed light on the causes of this difference, namely with respect to banking regulation, bank activity diversification and sources of funding for bank activities. To compare the risk profiles of state-owned, private and foreign banks, we estimate the Distance to Default as a market-based measure, which is defined as the deviation of the market value of banks' assets from the default event, and an improved Z-score as an accounting-based measure.

There are many reasons to suppose that CEE banks have different risk profiles according to their ownership structure. During the beginning of the transition period, domestic private banks did not have the experience and knowledge to monitor and produce information about their investments. Moreover, they frequently operated with objectives other than those of 
profit-oriented ones, such as, for example, the personal enrichment of managers (Bonin et al., 1998). All these and others led them to conduct high-risk activities that have sometimes overstepped the prudential principles of bank behaviour.

State-owned banks may also be distorted from profit-oriented objectives. Politicians may use these banking institutions to transfer funds to their supporters (Shleifer and Vishny, 1986; Shleifer, 1998) or to pursue their own political goals (Iannotta et al., 2013). Regarding CEE countries, some authors show that, during the beginning of the transition period, their governments financed and developed tax policies, kept state enterprises active and promoted exports through and thanks to their banks (OECD, 1996, Bonin et al., 1998), which weakened these institutions and made them riskier. And the market could perceive them as such. On the other hand, in spite of their worse financial performance, state-owned banks may benefit from an implicit government guarantee (Faccio et al., 2006). The relevant question is whether this guarantee is trustworthy for CEE economies, where state-owned banks were too big to be bailed out by governments with high budget deficits.

As regards foreign banks, they inherit obviously risk profiles of their parent institutions. Because the foreign banking institutions are mostly from well-developed countries, namely from Western Europe, and because they could be always bailed out by their parent banks, there are reasons to suppose that they would be favourably considered by market regarding their risk. But over time, as domestic private banks accumulate experience and knowledge, and provide the same products and services as foreign institutions, the difference in risk profiles between these two forms of ownership could become less marked.

We thus investigate the following research questions: Is there a significant difference in risk profiles between foreign, private and state-owned banks? Is such a difference related to the way in which banks finance their activities and to bank activity diversification? Finally, does banking regulation affect the risk-taking and thus the risk perception of banks? In order 
to address these questions, we estimate the risk of foreign, private and state-owned banks and compare them on a sample of CEE banks over the 1995-2013 period.

This study allows to deepen the understanding of these questions in several ways. First, contrary to many other studies on the subject, we consider market perceptions about risk as well an accounting measure. For the market measure, our methodology is based on estimates of the Distance to Default and the market risk is there considered through the banks' equity prices. This allows us to avoid many shortcomings of traditional measures of bank risk, which are explained later in the paper. Some of them have been nevertheless overcome by the improvement of the most used risk measure, which is the Z-score.

Second, we extend our investigation to factors that could affect differently the risk of foreign, private and state-owned banks. For example, the tightening of banking regulation could increase the bank risk and the likelihood of bank crises (Barth et al., 2001, 2004; González, 2005), but may have a different effect according to risk profiles of banks (Klomp and De Haan, 2012). The same question is addressed to the source of bank activity financing, because foreign, private and state-owned banks have different implicit guarantees on their financing, and to bank activity diversification, because these institutions have different composition of their products and services (De Haas et al., 2010).

Third, this paper also includes the recent financial crisis as well the precedent ones and thus allows to investigate the evolution of the risk of these banks. Distinguin et al. (2013) implicitly examine the risk-taking behaviour of state-owned banks - treating it as a control variable in their investigation - and obtain the unexpected result that state-owned banks are the least risky. Many other studies show an opposite finding based on the experience of the Western European (Iannotta et al., 2007, 2013) and Asian banking institutions (Laeven, 1999; Chou and Lin, 2011). While most available studies on the subject - except those on Western Europe - take generally international comparative approach with banks belonging to countries 
characterised by significant differences in banking regulation, we focus on the new EU member states, which share a system of common banking regulatory rules imposed by the EU directives. Moreover, the foreign banks that have entered these markets since the early 1990s are essentially from Northern and Western Europe and USA and, consequently, have changed considerably the risk-taking practices of domestic banks.

In order to investigate the risk of CEE banks and the role of ownership structure, in section 2, we explain why most applied methodologies to measure the bank risk are inconsistent and propose new two measures of bank risk: an improved Z-score, as an accounting-based measure, and the Distance to Default, as a market-based measure. Section 3 describes and explains our data and construction of bank regulatory variables. Section 4 presents our results and comments, and Section 5 evaluates whether our results are robust. Section 6 summarises our main findings and concludes.

\section{Methodology: alternative measure of the Z-score and the Distance to Default}

Our methodology consists of estimating the expected return and volatility of bank assets in order to compute an improved Z-score and the Distance to Default of banks. These measures are very different from other risk measures that are largely applied in banking and we explain, in this section, the reasons behind our choice and describe various estimation procedures of Distance to Default.

\subsection{Accounting-based bank risk measures and conceptual inconsistency of the Z-score}

There are many ways in banking literature to measure the bank risk. One of them consists to use accounting bank data and another way consists to estimate the risk throughout the market perception. We present here the most used bank risk indicators, their shortcomings and advantages. 


\subsubsection{Accounting-based measures of bank risk}

The first and most applied is based on the use of accounting ratios measuring essentially the bank's asset quality and profitability, as ratios of Loan Loss Provisions and of Impaired Loans to Total Loans and as standard deviations of Returns on Assets and of Returns on Equities. The advantages of these ratios are the easiness of their computation and data availability for all banks. However, they have some major drawbacks. A typical problem in analysing the risk based on these ratios is the endogeneity because the dependent variable often affects the risk variable in the first place (Berger, 1995). Another important shortcoming is the inconsistency with the risk concept provided by these measures. With standard deviations of returns on equity and assets, a bank is considered risky if it engages in activities that generate returns that are either higher or lower than the average return, which seems to be contradictory. However, a bank cannot be considered necessarily risky if its returns are higher than a certain average level. Another drawback of this approach is that, according to the same measures, banks whose returns are higher and lower with the same extent with respect to the average value of returns are equally risky. Finally, the standard deviations are either estimated on a very limited number of observations, which make them not so precise, or based on distant past annual observations, which make them not so flexible for a too long period. Moreover, their empirical computations do not correspond to their real values if the distribution is not symmetric.

\subsubsection{Z-score and its shortcomings}

One attempt to address the endogeneity problem and the inconsistency with a risk measure of above ratios is by the Z-score, based on a bank's leverage and the mean (in the numerator) and volatility of its returns on assets (in the denominator). Thus, the involvement 
in high-return activities increases the Z-score, which indicates a decrease in bank risk and contrasts somewhat with the results of the standard deviation approach.

Nevertheless, three important problems could be mentioned. First, the Z-score formula, i.e. $Z=\frac{C A R+E(R O A)}{\sigma(R O A)}$, supposes that the returns on assets, $R O A$, random variable is normally distributed (Boyd and Runkle, 1993, Hannan and Hanweck, 1988, and Boyd et al., 1993). Another constraint is the definition of the default event that occurs when the current losses exhaust capital or, equivalently, when the bank's profits, $\Pi$, are lower than its negative capital, $-C$. If the bank assets are denoted by $A$, then the probability of default can be written as

$$
\begin{aligned}
\operatorname{Pr}[\Pi \leq-\mathrm{C}] & =\operatorname{Pr}[\mathrm{ROA} \leq-\mathrm{CAR}] \\
& =\operatorname{Pr}\left[\frac{\mathrm{ROA}-\mathrm{E}(\mathrm{ROA})}{\sigma(\mathrm{ROA})} \leq-\frac{(\mathrm{CAR}+\mathrm{E}(\mathrm{ROA}))}{\sigma(\mathrm{ROA})}\right],
\end{aligned}
$$

where $R O A=\Pi / A$ is the return on assets random variable, $C A R=\mathrm{C} / A$ is the capital on assets ratio, $E(R O A)$ is the expected value of $R O A$ and $\sigma(R O A)$ its standard deviation. With the assumption of normal distribution for $R O A$, probability of default becomes

$$
\begin{aligned}
\operatorname{Pr}[\Pi \leq-\mathrm{C}]= & \operatorname{Pr}[\mathrm{ROA} \leq-\mathrm{CAR}]=N\left[-\frac{(\mathrm{CAR}+\mathrm{E}(\mathrm{ROA}))}{\sigma(\mathrm{ROA})}\right] \\
& =1-N[\mathrm{Z}]
\end{aligned}
$$

where $N($.$) is the normal cumulative distribution function. Thus, higher is the Z-score lower$ is this probability. But these two constraints, the definition of the default event and the normality assumption of the $R O A$ random variable, are major shortcomings of the Z-score computation. This definition excludes any possibility for banks to cover their losses and liabilities with their assets. Because banks can always use their assets to meet their commitments, bank assets must be included in the definition of the default event. As for normal distribution, it has a perfect symmetric form, which allows the transformation 
$N[-Z]=1-N[Z]$ and, in consequence, the deduction of the $Z$-score formula, which is contrary to usually observed asymmetric (skewed) distribution for $R O A$.

Second, Boyd and Runkle (1993), Hannan and Hanweck (1988) and Boyd et al. (1993) argue that even if $R O A$ is not normally distributed, by the Bienaymé-Tchebycheff inequality, the $Z$-score remains still a good measure of bank risk and becomes the inverse measure of the upper bound of the probability of default, because

$\operatorname{Pr}[R O A \leq-C A R]=\operatorname{Pr}[R O A-E(R O A) \leq-(C A R+E(R O A))] \leq \frac{\sigma^{2}(R O A)}{2(C A R+E(R O A))^{2}}=\frac{1}{2 Z^{2}}$

This inequality is valid for any symmetric distribution of $R O A$. If this random variable is skew distributed, then one may apply Cantelli's inequality that lead to the following expression for the probability of default:

$$
\operatorname{Pr}[R O A \leq-C A R] \begin{cases}\leq \frac{1}{1+Z^{2}}, & \text { if } C A R+E(R O A)>0 \\ \geq \frac{Z^{2}}{1+Z^{2}}, & \text { if } C A R+E(R O A)<0 .\end{cases}
$$

The increase in Z-score reduces the upper limit and raises the lower limit, and the opposite effect is observed for the decrease in Z-score. But having an interval for the probability of default provides no information about its true value. For this reason, Z-score, without normal distribution assumption, cannot ensure the comparability of bank risk data. Moreover, the convergence of the true value of the default probability to its upper limit will intrinsically depend on the properties of the statistical law of $R O A$ random variable.

Third, from the estimation point of view, Z-score is based on the determination of the expected value and standard deviation of the bank's returns on assets. This implies the shortcomings of such computation mentioned above; that is, either the precision insufficiency of the standard deviation or its lack of flexibility on a too long period. Moreover, the empirical estimations of the mean and standard deviation may be very different from their 
true values, i.e. expected value and standard deviation of the distribution, if the former is not symmetric.

\subsubsection{Improved Z-score}

Taking into account the aforementioned shortcomings of Z-score, namely the possible asymmetry of the $R O A$ distribution and the incoherent empirical estimations of the average and standard deviation values, we will consider an asymmetric (skew) normal distribution for the returns on assets, with the following cumulative distribution function $F(x, \alpha)$ :

$$
F(x, \alpha)=N(x)-2 T(x, \alpha)
$$

where $T(x, \alpha)$ is the Owen (1956) function

$$
T(x, \alpha)=\frac{1}{2 \pi} \int_{0}^{\alpha} \frac{\mathrm{e}^{-\frac{1}{2} x^{2}\left(1+t^{2}\right)}}{1+t^{2}} \mathrm{~d} t
$$

If $\alpha=0$, then $T(x, 0)=0$ and $F(x, 0)=N(x)$; otherwise, if $\alpha<0, T(x, \alpha)<0$ and

$F(x, \alpha)>N(x)$, and for $\alpha>0, T(x, \alpha)>0$ and $F(x, \alpha)<N(x)$. The parameter $\alpha$ takes into account the asymmetry (skewness) of the distribution. We thus observe that for left skewed distribution $(\alpha<0)$ the true probability of default is higher than that computed with the supposed normal distribution (with the same minus Z-score), and vice versa, for the right skewed $(\alpha>0) R O A$ distribution the true probability of default is lower than that estimated with the normal distribution.

Thus, the probability of default is computed as $\operatorname{Pr}[R O A \leq-C A R]=F\left(\mu_{1}, \sigma_{1}, \alpha,-C A R\right)$, where $\mu_{1}, \sigma_{1}$ and $\alpha$ are location, scale and skew parameters, respectively. In order to make these results comparable with those obtained from the traditional Z-score estimates, we compute an improved Z-score measure extracted from this skew normal distribution. Because according to the traditional approach (eq. 2) minus Z-score is the point at which the normal cumulative distribution function is equal to the probability of default, our minus improved Z- 
score will be the point at which the $N($.$) function is equal to the probability of default$ computed with the skew normal cumulative distribution function, as follows:

$$
\text { Zscore1 }=-N^{-1}\left(F\left(\mu_{1}, \sigma_{1}, \alpha,-C A R\right)\right) \text {. }
$$

We also estimate and apply a Z-score issued, according to equation (2), from a normal distribution, that is

$$
\text { Zscore } 2=\frac{C A R+\mu_{2}}{\sigma_{2}}
$$

where $\mu_{2}$ and $\sigma_{2}$ are location and scale parameters, respectively, for the normal distribution of $R O A$, and for such distribution $\mu_{2}=E(R O A)$ and $\sigma_{2}=\sigma(R O A)$. Finally, for comparability reason the traditional Z-score measure is also computed:

$$
\text { Zscore3 }=\frac{C A R+\operatorname{mean}(R O A)}{\operatorname{sigma}(R O A)},
$$

where mean $(R O A)$ and $\operatorname{sigma}(R O A)$ are, respectively, empirical estimates of mean and of standard deviation of $R O A$ within three years window.

\subsection{Market-based measure of bank risk: the Distance to Default}

In addition to the methodology's non-alignment with the concept of risk, the previously mentioned measures do not indicate the market's perceptions of risks taken by banks. This is an important shortcoming because the market ultimately perceives the riskiness of banks' activities and gauges their potential insolvency. The market evaluates whether banks hold enough assets to cover their liabilities and commitments entirely. In addition, market-based measures allow overcoming the above mentioned problems and incorporate not only the bank's financial conditions described by the accounting variables, but also the bank's management quality, governance, organisation. 
A second approach is based on the estimation of a market measure, which is the Distance to Default from the option model of Merton (1974). ${ }^{1}$ This risk measure shows how far banks are from the default event. The main advantages are as follows. First, within the Merton framework, we redefine the default state and regard banks as insolvent when the market value of their assets is lower than a certain threshold and therefore cannot cover the market value of their liabilities (debt). Thus, we take into account the market perception of banks' risk. Second, we estimate the Distance to Default as a measure of bank risk as the "distance" between the current situation of the bank and its default state; thus, the greater that the Distance to Default is, the less risky banks are, and vice versa. Third, the involvement of banks in higher-return activities is not necessarily considered risky (as for standard deviation measure) as long as the value of banks’ assets is sufficiently high to cover their liabilities.

A main shortcoming of this approach is that many banks of our sample are not listed in a stock exchange and one may not estimate the market values of assets and, in consequence, the Distance to Default for non-listed banks.

\subsection{Distance to Default estimation model}

In Merton's (1974) model, the value of bank assets is assumed to follow geometric brownian motion and bank liabilities consist of zero-coupon debt and common equity. A bank finances its assets through debt and equity. Thus, it is considered solvent as long as the market value of its assets covers its debt. Because the market value of these assets, $V_{t}$, is not observable, it is our state variable to be computed. To this end, we use the optional model in which equity and debt are regarded as contingent claims on assets. In the banking literature, this approach is widely applied to price deposit insurance (Duan and $\mathrm{Yu}, 1994$; Ronn and

\footnotetext{
${ }^{1}$ Another market approach consists to use credit ratings, provided by well known rating agencies. Because they are available for very few CEE banks and years, we cannot apply them for this study. In addition, many banks remain for a long time with the same rating, which is inconsistent with quite a hectic period in which evolved the CEE economies.
} 
Verma, 1986) or to estimate individual bank risk (Laeven, 2002, Vassalou and Xing, 2004) and the systemic risk of the banking industry (Lehar, 2005).

Given that bank assets are fully financed by equity $S_{t}$ and debt $D_{t}^{m}$, the following balance-sheet identity holds for any time $t: V_{t}=S_{t}+D_{t}^{m}$, where all variables are expressed in market values. To avoid a negative value for equity, banks will not reimburse their creditors if the market value of their assets is lower than the market value of their debt. Within the Merton framework, a bank's equity might thus be regarded as a call option on the bank's assets, whose strike price is the book value of the bank's debt, $D$. To describe the evolution of the market value of the bank’s assets, $V_{t}$, follows a geometric brownian motion:

$$
\frac{d V_{t}}{V_{t}}=\mu_{V} \mathrm{~d} t+\sigma_{V} \mathrm{~d} W_{t}
$$

where $\mu_{V}$ and $\sigma_{V}$ are the expected return and return volatility of the market value of the bank's assets, respectively, and $W_{t}$ is a Wiener process. The risky debt $D$ is a zero-coupon bond with a maturity $T$ and interest rate $r$; thus, it grows at the rate $r$. Its market value at time $t, D_{t}^{m}$, prior to maturity, and that of equity, $S_{t}$, are expressed through Black and Scholes's (1973) model:

$$
\begin{aligned}
& S_{t}=V_{t} N\left(d_{t}\right)-D e^{-r(T-t)} N\left(d_{t}-\sigma_{V} \sqrt{T-t}\right), \\
& D_{t}^{m}=V_{t}-S_{t}=V_{t} N\left(-d_{t}\right)+D e^{-r(T-t)} N\left(d_{t}-\sigma_{V} \sqrt{T-t}\right),
\end{aligned}
$$

where $N($.$) is the standard normal cumulative distribution function and$

$$
d_{t} \equiv \frac{\ln \left(V_{t} / D\right)+\left(r+\frac{1}{2} \sigma_{V}^{2}\right)(T-t)}{\sigma_{V} \sqrt{T-t}} .
$$

Solving equation (7) and noting $Z_{t} \equiv \frac{W_{T}}{\sqrt{T-t}}$, where $Z_{t} \rightarrow N(0 ; 1)$, the market value of the bank's assets at debt maturity $T$ is $V_{T}=V_{t} \exp \left[\left(\mu_{V}-0.5 \sigma_{V}^{2}\right)(T-t)+\sigma_{V} \sqrt{T-t} Z_{t}\right]$, where $Z_{t}$ could be interpreted as the standardised return. The market value of equity, $S_{t}$, is the stock 
value of listed banks and is thus an observable variable, as well the book value of total debt, $D_{t}$.

Unlike Z-score, within this approach, banks can cover their debts with their assets, and they are considered solvent as long as this condition is respected at debt maturity. We thus define default as when the market value of the bank's assets at maturity is lower than that of its debt, $V_{T}<D$. As the Distance to Default is represented by the following expression:

$$
D D_{t} \equiv \frac{\ln \left(V_{t} / D\right)+\left(\mu_{V}-\frac{1}{2} \sigma_{V}^{2}\right)(T-t)}{\sigma_{V} \sqrt{T-t}},
$$

the condition for default can be rewritten as $Z_{t}<-D D_{t}{ }^{2}$

The Distance to Default (DD), or more precisely its negative value, is therefore defined as the smallest standardised return of the bank's assets below which the bank defaults. Thus, values of $D D$ that are close to zero or negative indicate a risky situation for the bank; the lower that the value of $D D$ is, the closer the bank is to insolvency, which occurs when the mean of the bank's asset returns, $\mu_{V}-0.5 \sigma_{V}^{2}$, is negative and the current market value of the bank's assets is lower than the book value of its debt. This market-based measure of bank risk can be computed only if the unobserved market value of assets, $V_{t}$, and the model parameters, $\mu_{V}$ and $\sigma_{V}$, can be estimated.

\subsection{Estimation procedure}

Three estimation procedures are used in the banking literature to estimate the market value of a bank's assets and the model parameters, $\mu_{V}$ and $\sigma_{V}$ : the KMV estimation approach, Ronn and Verma’s (1986) procedure and Duan’s (1994) method. Nevertheless, we focus on the KMV and Duan estimates because they theoretically and statistically respect the

\footnotetext{
${ }^{2}$ The standardised return and the Distance to Default are estimated from time $t$ to maturity $T$.
} 
hypotheses of the option model and geometric brownian motion. Moreover, Duan et al. (2005) prove the equivalence between the KMV and Duan estimates,

Unlike the bank's assets $V_{t}$, the equity market values $S_{t}$ are observed at regular time intervals, more precisely every trading day. Given the book value of the bank debt $D$, equations (8) and (10) make up a one-to-one relationship between asset values and equity prices, which allows for the estimation of our state variable $V_{t}$. Our equity sample is of a daily frequency and our debt sample is of a monthly frequency. The assets value will therefore be computed daily through equation (8), where the debt value $D_{p}$ is constant during the month $p$. For the two estimation approaches, the value of the bank's assets and the model parameters are estimated by assuming that the maturity of debt $T$ is equal to one year $(T=1)$ and using a six month rolling window.

Let $m$ denotes the number of months in our entire sample and $n_{j}$ the number of days within the estimation window $j$, where $j=p-5$ and $p=[6, \ldots, m]$. Because the capital markets in our transition economies were created in the early and mid-1990s, the lack of historical bank stock prices led us to reduce the historical reference with respect to that typically used for developed countries. ${ }^{3}$ Thus, we made estimations for the current month and for the past five months. We therefore express the time series of $n_{j}$ daily observations within the estimation window $j$ of the bank's market capitalisation by $\left\{S_{1, j}, \ldots, S_{n_{j}, j}\right\}$, considering 260 trading days per year.

For each trading day of a given month $p$ and of the last five months, we compute the implicit market value of the bank's assets using the month $p$ 's level of debt. For this month $p$, we then estimate the expected return and the volatility of the bank's asset returns. Finally, we roll the estimation window forward by one month and estimate all unknown model parameters, $\mu_{V}$ and $\sigma_{V}$, for all months of our sample period, except the first five months. The

\footnotetext{
${ }^{3}$ Vassalou and Xing (2004), for instance, applied an estimation window of 12 months for American firms.
} 
Distance to Default is also computed for each month, more precisely for the last trading day of the month.

By contrast to a broad stream of the literature that employs a risk-free interest rate, we consider the debt interest rate $r_{i}$ to be specific to each bank $i$. Even if in the case of economywide troubles the banks are subject to the same conditions on the market, the effects on their own economic and financial situation could be and are, in most cases, different. Employing own interest rate for each bank allows us to account for each bank's debt and its evolution, and to be more precise regarding its risk.

\subsubsection{KMV estimation approach}

The KMV estimation approach is a two-step iterative algorithm. Beginning with an arbitrary value of the asset return volatility $\hat{\sigma}_{V, j}^{(0)}$, in the first step we compute the first series of the implied asset value $\left\{\widehat{V}_{1, j}\left(\hat{\sigma}_{V, j}^{(0)}\right), \ldots, \widehat{V}_{n_{j}, j}\left(\hat{\sigma}_{V, j}^{(0)}\right)\right\}$, where $\widehat{V}_{i, j}\left(\hat{\sigma}_{V, j}^{(0)}\right)$ is estimated for each trading day $i$ of the estimation window $j$ using equations (8) and (10). In the second step, we compute the asset returns and their volatility, which are used for the next iteration. For the $k^{\text {th }}$ iteration, these two steps can be generalised from equations (8) and (10) as follows:

$$
\begin{aligned}
& S_{i, j}=V_{i, j}^{(k)} N\left(d_{i, j}^{(k)}\right)-D_{p, j} e^{-r_{i, j}\left(1-t_{i, j}\right)} N\left(d_{i, j}^{(k)}-\hat{\sigma}_{V, j}^{(k-1)} \sqrt{1-t_{i, p}}\right), \\
& d_{i, j}^{(k)} \equiv \frac{\ln \left(V_{i, j}^{(k)} / D_{p, j}\right)+\left(r_{i, j}+\frac{1}{2} \hat{\sigma}_{V, j}^{(k-1)}\right)\left(1-t_{i, p}\right)}{\hat{\sigma}_{V, j}^{(k-1)} \sqrt{1-t_{i, p}}},
\end{aligned}
$$

where $p=[1, \ldots, m]$. For all days $i$ belonging to month $p, D_{p, j}$ is constant. $t_{i, p}=\left(i^{\prime}-1\right) / 260$, where $i^{\prime}=\left[1, \ldots, n_{p}\right]$ has a one-to-one relationship with $i$, and $n_{p}$ is the number of trading days within month $p$.

In the second step, we estimate the implied asset returns $\left\{\hat{R}_{2, j}^{(k)}, \ldots, \hat{R}_{n_{j}, j}^{(k)}\right\}$ and update the return volatility of the bank's assets as follows: 


$$
\begin{array}{ll}
\hat{R}_{i, j}^{(k)}=\ln \hat{V}_{i, j}^{(k)}-\ln \hat{V}_{i-1, j}^{(k)}, & \forall i \in\left[2, n_{j}\right] \text { and } j=p-5 \text { with } p \in[6, m] \\
\bar{R}_{j}^{(k)}=\frac{1}{n_{j}-1} \sum_{i=2}^{n_{j}} \hat{R}_{i, j}^{(k)}, & \hat{\sigma}_{V, j}^{(k)}=\sqrt{\frac{260}{n_{j}-2} \sum_{i=2}^{n_{j}}\left(\hat{R}_{i, j}^{(k)}-\bar{R}_{j}^{(k)}\right)^{2} .}
\end{array}
$$

This iterative procedure is repeated until the values of $\hat{\sigma}_{V, j}^{(k)}$ and of $\hat{\sigma}_{V, j}^{(k-1)}$ converge, and our tolerance level is 10E-8. As discussed above, the length of time is measured in years and consequently all parameters are estimated on an annual basis. The same is done for $t_{i, p}$, which denotes the time between the first day and day $i$ of month $p$. The initial value of the asset return volatility is considered to be the volatility of the equity return, $\hat{\sigma}_{V, j}^{(0)}=\hat{\sigma}_{S, j}$, with $\hat{\sigma}_{S, j}=\sqrt{\frac{260}{n_{j}-2} \sum_{i=2}^{n_{j}}\left(\hat{R}_{i, j}^{S}-\bar{R}_{j}^{S}\right)^{2}}, \hat{R}_{i, j}^{S}=\ln S_{i, j}-\ln S_{i-1, j}$ and $\bar{R}_{j}^{S}=\frac{1}{n_{j}-1} \sum_{i=2}^{n_{j}} \hat{R}_{i, j}^{S}$.

After achieving convergence, for the $\bar{k}^{\text {th }}$ iteration, we estimate for each month the expected return on an annual basis:

$$
\hat{\mu}_{V, j}=260 \bar{R}_{j}^{(\bar{k})}+0.5\left(\hat{\sigma}_{V, j}^{(\bar{k})}\right)^{2}
$$

Because the amount of debt is known only for the end of month, the Distance to Default is estimated monthly on an annual basis with the end-of-month asset value:

$$
D D_{n_{j}, j}=\frac{\ln \left(V_{n_{j, j}}^{(\bar{k})} / D_{p, j}\right)+\left(\hat{\mu}_{V, j}-\frac{1}{2}\left(\hat{\sigma}_{V, j}^{(\bar{k})}\right)^{2}\right)\left(1-t_{n_{p}, p}\right)}{\hat{\sigma}_{V, j}^{(\bar{k})} \sqrt{1-t_{n_{p}, p}}}
$$

\subsubsection{Duan's (1994) estimation approach}

Duan $(1994,2000)$ develops a maximum likelihood estimator of the model parameters $\mu_{V}$ and $\sigma_{V}$ that is consistent with the stochastic equity volatility assumption of Merton's (1977) model. With a geometric brownian motion in equation (7), Duan $(1994,2000)$ constructs the following log-likelihood function for the model parameters, which is maximised considering the values of the bank's assets: 


$$
\begin{aligned}
L_{S, j}\left(\mu_{V}, \sigma_{V}\right)= & -\frac{n_{j}-1}{2} \ln \left(\frac{2 \pi \sigma_{V}^{2}}{260}\right)-\sum_{i=2}^{n_{j}} \ln \widehat{V}_{i, j}\left(\sigma_{V}\right)-\sum_{i=2}^{n_{j}} \ln \left(N\left(\hat{d}_{i, j}\left(\sigma_{V}\right)\right)\right) \\
& -\frac{260}{2 \sigma_{V}^{2}} \sum_{i=2}^{n_{j}}\left[\ln \left(\frac{\widehat{V}_{i, j}\left(\sigma_{V}\right)}{\widehat{V}_{i-1, j}\left(\sigma_{V}\right)}\right)-\frac{\left(\mu_{V}-\frac{1}{2} \sigma_{V}^{2}\right)}{260}\right]^{2},
\end{aligned}
$$

where $\hat{d}_{i, j}\left(\sigma_{V}\right)$ corresponds to $d_{i, j}$, with $\widehat{V}_{i, j}\left(\sigma_{V}\right)$ instead of $V_{i, j}$. In this expression, the following computation has been applied: $\partial S_{t} / \partial V_{t}=N\left(d_{t}\right)$. This log-likelihood function is directly dependent on the market values of the bank's equity through the solution $\widehat{V}_{t}\left(\sigma_{V}\right)$. To compute the parameters $\mu_{V}$ and $\sigma_{V}$, an iterative optimisation procedure can be applied. Using the expected asset returns and asset return volatilities of the first approach as the starting values for $\mu_{V}$ and $\sigma_{V}$, respectively, and given data on the values of equity $S_{i, j}$ and debt $D_{p, j}$, equation (8) is solved to yield the sample of bank asset values $\widehat{V}_{i, j}$. Equation (18) is then used to find the values of $\hat{\mu}_{V}$ and $\hat{\sigma}_{V}$ that maximise this likelihood function. As in the first method, these two parameters are computed for each estimation window and, as we roll this window forward by one month, we obtain monthly estimations for annual values of $\hat{\mu}_{V}$ and $\hat{\sigma}_{V}$ for the entire sample except for the first five months.

\section{Data analysis}

In this section, we first present our sample and then explain the selection and construction of explanatory and control variables.

\subsection{Sample presentation}

Our sample of countries consists of ten Central and Eastern European economies that are new EU members: Bulgaria, the Czech Republic, Hungary, Estonia, Latvia, Lithuania, Poland, Romania, Slovakia and Slovenia, for accounting-based risk measures and eight of them for the Distance to Default. For the market-based risk indicator, our selection of 
countries was based on data availability, which is mostly related to the lack of data on stock prices. Because these data are not publically available for Estonian and Latvian banks, the Distance to Default is not computed for these banking institutions. Accounting data for individual banks are extracted on an annual basis from Bankscope Fitch IBCA. The interest rate on banks' debt is estimated as the ratio of interest expenses to total debt. To obtain monthly series for debt and interest rate, we converted the yearly series of total debt and interest expenses through the cubic method. Daily stock prices are obtained from DataStream. The sample period is from 1995 to 2013.

\subsection{Explanation of variables}

Our dependent variable is one of aforementioned measures of bank risk: accountingbased measures of risk (Zscore1 and Zscore3) and market-based measure of risk (the Distance to Default). We will not keep Zscore2, because, how we will observe, it has the same evolution as that of Zscore1. The Distance to Default is estimated according to the two approaches explained above. For the book value of debt $D$, we use "Total liabilities", that is, both short- and long-term debts. As explained by Vassalou and Xing (2004), it is important to include long-term debts because the interest payments in the service of these debts are part of short-term liabilities. Moreover, the size of long-term debts affects the ability of banks to handle short-term debts and, consequently, affects their solvency. However, there is no consensus about how much of long-term debts should enter into the calculation of the Distance to Default. KMV uses an arbitrary weight of 50 percents, but we decided to include the entire amount of long-term liabilities. These measures of bank risk are regressed on a set of explanatory variables that are explained below.

\subsubsection{Ownership structure}


To study the differences in bank risk according to ownership structure, we construct two dummy variables: FOR and PRIV. The first variable takes the value of one if the share of foreign ownership is higher than 50 percents, and zero otherwise. The dummy variable PRIV takes the value of one if domestic private ownership comprises at least 50 percents of total shares, and zero otherwise. When multiplied by bank and country variables, they reveal the differences among ownership forms in terms of the effects of these variables on bank risk.

\subsubsection{Bank characteristics}

We consider certain variables whose effects on bank risk are important and of great interest. We use the share of deposits received from other banks in total deposits (BDTD). According to Nier and Baumann (2006), and Distinguin et al. (2013), this indicator is a good measure of market discipline because interbank deposits are not covered by any deposit protection schemes, which might persuade banks to temper their risk-taking behaviour. We complete this analysis of the effects of bank liability structure by incorporating the share of long-term funds in total funds (LTFTF). From an ex-ante perspective, a higher share of deposits from other banks in total deposits might reduce incentives for banks to take more risks, a result that was found by Distinguin et al. (2013) for CEE banks with the BDTD variable. Conversely, banks with higher ratios of bank deposits to total deposits that have not been previously "disciplined” in the interbank market might be perceived as riskier because they are subject to higher liquidity risks. These two opposite effects imply an ambiguous general effect. However, by contrast to Distinguin et al. (2013), we expect the latter effect to prevail. It is unlikely for market discipline to be effective before the occurrence of any crisis event. Moreover, we consider the withdrawal of bank deposits to be more important during crises; consequently, the banks that hold more bank deposits might be riskier. By contrast to 
the effects of bank deposits, long-term funds cannot be withdrawn and may therefore serve as a "spare tyre” during banking crises.

A bank's business model also affects its risk-taking behaviour. Because we have no details about the structure of banking activities, we use the ratio of interest income to total operating income (IIOI) to proxy for the bank business model. Higher values of this ratio characterise the concentration on interest-bearing activities, which may make CEE banks riskier.

\subsubsection{Country characteristics}

Two country-level variables are considered in our estimations. Demirgüc-Kunt and Detragiache (2002) find that the quality of law enforcement affects the risk-taking behaviour of banks. Moreover, this impact can be different according to the risk profiles of banks (Klomp and De Haan, 2012). In our estimations, we thus examine the effects of the enforcement of the banking regulation and banking supervision, and, for this reason, we construct a Banking Regulation Index (BRI). The construction procedure and composition of this index are explained in detail in Appendix A. According to this procedure, the index takes values ranging between zero and one, which allows it to be comparable across countries. Environments in which laws are enforced to a greater extent correspond to values that are closer to one. The effects of the regulation may be ambiguous: either tightening of the banking regulation increases the bank risk (Barth et al., 2001, 2004; González, 2005) or, on the contrary, it limits the banks' risk-taking behaviour (Klomp and De Haan, 2012).

The second country-level variable that might affect the bank risk is the annual growth rate of the real Gross Domestic Product (RGDPG), which allows for the economic conditions and macroeconomic cycle to be taken into account. We expect a higher real GDP growth rate to reduce the bank risk. 


\section{Econometric method and empirical analysis}

In this section, we first check the consistency of the traditional Z-score, namely the symmetric distribution of the $R O A$ random variable and then study the effects of ownership structure on the CEE banks’ risk.

\subsection{Empirical inconsistency of the traditional Z-score as a measure of bank risk}

In order to estimate Zscore1 and Zscore2 measures, we determined respectively the skew normal and normal distribution functions for each bank that has at least ten observations for $R O A$. If this variable has a symmetric distribution, which is the main principle of the traditional Z-score concept, then, as mentioned in section 2, $\alpha=0$ and Zscore1 $=$ Zscore2. However, our estimations for all countries provide following range of results for skew parameter $\alpha$ : for Bulgaria $\alpha \in[-4.00 ; 3.73]$, for the Czech Republic $\alpha \in[-4.20 ; 3.83]$, for Hungary $\alpha \in[-3.83 ; 3.96]$, for Estonia $\alpha \in[-4.34 ; 3.50]$, for Latvia $\alpha \in[-4.37 ; 4.53]$, for Lithuania $\alpha \in[-4.86 ; 4.81]$, for Poland $\alpha \in[-4.48 ; 4.26]$, for Romania $\alpha \in[-4.38 ; 3.91]$, for Slovakia $\alpha \in[-5.06 ; 4.61]$, and for Slovenia $\alpha \in[-4.02 ; 3.91]$. These results of skew parameter $\alpha$ clearly show that the traditional Z-score approach is not consistent, at least for CEE banks. This is why we will focus on Zscore1 as an accounting-based risk measure and we will keep the results of Zscore3 only for comparability reason.

\subsection{Evolution of the bank risk}

As aforementioned, in order to assure the reliability of estimations, the parameters of the distribution functions (skew normal distribution for Zscore1 and normal distribution for Zscore2) are determined only for banks with at least ten observations of ROA within 19952013 period. As for Zscore3, it is computed within three years rolling window, and these 
results and those for the Distance to Default, estimated with both methods, are presented in table 1.

For all countries, we observe the same evolution of Zscore1 and Zscore2, but a high discrepancy between these measures and Zscore3, and equivalent results for the Distance to Default obtained through the KMV and Duan methods.

Though these estimates the inconsistency of Zscore3 is confirmed. It is no explanation why it rises highly in 2000, 2002 and namely in 2008 and 2011 for Bulgarian banks, which means that the bank risk decreased, for example, twofold in 2002 and threefold in 2008. Moreover, the very erratic evolution between 2008 and 2013 is also very strange. Such evolutions are observed for all other countries: for the Czech Republic after 2001 with a peak in 2009, for Hungary with two peaks in 1999 and 2006, for Estonia with highest values in 2003 and 2004, and fifty times less during the 2009-2011 period. Zscore3 of Lithuanian banks shows a similar motion. The Polish banks have their highest Zscore3 in 2012 and 2013, and Romanian banks their lowest ones in 1997 and 1998. Conversely, the risk measured with Zscore3 is very low for Slovenian banks during the 1997-2003 period and it follows an erratic evolution for Slovak banks too.

Zscore3 behaves so extremely erratically because the standard deviation applied in its computation has an equivalent erratic motion: it is usually very high at the end of nineties, implying low Zscore3 and high risk, and very low during the twenties, with inverse effects on Zscore3 and, respectively, on risk. But such important variations could be also the result of high increases of $R O A$ and not only of decreases of this variable, and in this case they do not describe a risk situation.

Contrary to Zscore3, Zscore1 and Zscore2 are computed with the same standard deviation of a bank for the entire 1995-2013 period. Their evolution is, in consequence, more stable and really describes the probability of default and bank risk according to equations (1), (2), (4) 
and (5). Because their concept of computation is the same but with different distribution functions, Zscore1 and Zscore2 have the same evolution and, for all countries and all years, Zscore2 is higher than Zscore1. Thus, imposing a symmetric distribution for the $R O A$ random variable (a normal distribution, in our case) Zscore2 provides mistakenly lower values of risk, namely during the economy-wide troubles: 1995-2001 period for Bulgaria, 1995-1996 period for the Czech Republic, 1995-1999 and 2011-2013 periods for Estonia, 1995-1996 period for Latvia, 1995-2001 period for Lithuania, year 1996 of many bank failures for Romania, 19972002 for Slovenia. For the entire examined period the difference between Zscore1 and Zscore2 is important for the Slovak banks, and it is relatively low for the Polish banks. The two reasons, the same evolution of both risk measures and systematically incorrectly lower risk results for Zscore2, lead us to focus only on Zscore1 afterwards.

According to its results, we observe that, in average, the Slovak banks have the lowest risk and Estonian, Latvian and Romanian banks the highest risk, the difference being however weak. For many of CEE countries the risk increases slightly after twenties and for some of them it is also low at the end of nineties. Close values imply that the banks are equivalently capitalised with respect to their $R O A$ distribution. Some exceptions are the huge decreases of Estonian banks' capitalisation in 1997 and of the Lithuanian banking institutions in 1995. On the other hand, the banks raised highly their capitalisation in respect to their $R O A$ distribution in 1996 for Bulgaria, in 1996-1997 for the Czech Republic, in 1996 for Lithuania, in 1997 for Slovenia.

Unlike the accounting-based measures of risk, which consider the banks' capitalisation with respect to their $R O A$ distribution, the market-based measures provide the market perception about the bank risk. For banks from all the countries in our sample except Slovenia, table 1 shows that the Distance to Default is higher - and, consequently, the risk is lower - on average, than those of Slovak banks. Both the KMV and Duan approaches suggest 
that Bulgarian banks have, on average, the highest Distance to Default and that Slovenian and Slovak banks are the most vulnerable. Moreover, the Distance to Default is highest during the period from 2001 to 2007 for most of countries, which corresponds to the growth boom in the CEE economies. During the economic growth, the CEE banks have a Distance to Default that is 4 points higher, on average, than it was during the crisis of 1997 when the banking environment dramatically deteriorated, with highest difference for Czech and Slovak banks. The balance sheets of banks and market perceptions begin to improve after 1999 and the Distance to Default continues to increase until 2007. At the beginning of the 2007-2008 financial crisis, the Distance to Default drops by an average of 4.5 points, with highest drops for Bulgarian, Czech, Hungarian and Lithuanian banks. The most CEE banking markets begin to improve after 2010 or 2011, but it is not still the case for the Slovenian banking environment.

According to ownership structure, the discrepancies between Zscore1 and Zscore3 are also indubitable. The first is roughly five times lower, with the highest difference in 2003 for state-owned banks. It indicates that foreign banks are less risky than domestic private institutions, excepting the years 1995 and 1997 and 2007-2008 period, and that public banks are the least risky, which is also the case with Zscore3 estimates. The former indicator however reverses the comparison between private and foreign banks during the 2000-2004 period. According to it, domestic private institutions are less risky.

As for market perception, the two market-based measures indicate unambiguously that foreign banks are the least risky and, conversely, state-owned banks are riskiest during the crisis periods of 1997-2000 and of 2008-2013. The private institutions have the best perception of the market during the period of economic growth.

Thus, neither accounting-based risk measures nor market-based ones show clearly how ownership matters for risk profile of the CEE banks. The first type of indicators suggests that 
these banks are relatively well capitalised with respect to their $R O A$ distribution with the best capitalisation for state-owned institutions. The second one points out the lowest risk for foreign banks and the highest vulnerability for public banks during the crisis periods, and the best performance in terms of risk for private institutions throughout the economic growth.

The question is whether this result on risk profile of banks is due essentially to their ownership structure. Our further objective is thus to investigate the factors influencing the bank risk and also isolate the effects of the ownership structure, and to study how the effects of these factors depend on the banks' ownership profile.

\subsection{Factors influencing the bank risk}

To examine the effects of ownership structures and other factors on the bank risk, we regress the following panel data model with bank- and time-fixed effects:

$$
\operatorname{Risk}_{i, j, t}=\alpha_{0}+\sum_{k=1}^{n} \alpha_{k} X_{k, i, j, t}+\sum_{l=n+1}^{m} \alpha_{l} Y_{l, j, t}+\mu_{i}+\pi_{t}+\varepsilon_{i, j, t},
$$

where $R i s k_{i, j, t}$ is one of the following risk measures: DD_KMV, DD_Duan, Zscore1 and Zscore3, for the bank $i$ in country $j$ at year $t, n$ is the number of bank-specific variables $(n=4)$, $m-n$ is the number of country-specific variables ( $m=6$ because $m-n=2), X_{k, i, j, t}$ is the bankspecific factor that controls for the $k$-th characteristic of bank $i$ at year $t$ in country $j$, and $Y_{l, j, t}$ is the country-specific factor that controls for the l-th characteristic of country j. $\alpha_{0}, \alpha_{k}$ and $\alpha_{l}$ are parameters to be estimated, $\mu_{i}$ and $\pi_{t}$ are individual and time effects, respectively, and $\varepsilon_{i, j, t}$ is the error term. This equation is regressed with standard errors that are robust to heteroscedasticity.

The results of the role of ownership on the bank risk are presented in table 2. Two models are estimated, which differ according to the source of bank activity funding, that is, interbank deposits and long-term funds. For each of these, we find that ownership variables are 
significant (FOR and PRIV) for Distance to Default measures and Zscore1. Foreign and domestic private banks are perceived by the market as being less risky than state-owned institutions, and foreign banks are the least risky. The ownership effect is not only statistically significant but also economically considerable. Indeed, the Distance to Default of these banks is with 1.5 points higher for the KMV estimates and approximately with 1.2 points higher for the Duan estimates in comparison with those of state-owned institutions. The domestic private banks show a Distance to Default that is higher with 1.2 points for the KMV results and with 0.7 points for the Duan results. Similar figures are obtained for Zscore1. As expected, Zscore3 does not make any difference in the risk profile of banks in terms of their ownership structure.

Thus, the regression results show that ownership is relevant to market perceptions of bank risk and that state-owned banks are considered most vulnerable. Despite the implicit provision of insurance from the government, their non-commercial and policy-oriented practices make the market "worry". Additionally, it is not always evident that this insurance could be provided when the economic environment - and the government- are in turmoil. Moreover, Zscore1 also shows that the state-owned banks are riskiest; more precisely, they are less capitalised with respect to their $R O A$ distribution. Contrary to the previous point, the isolation of the ownership effects from the effects of other variables permits to reveal clear ownership effects on risk profile of CEE banks.

Bank vulnerability also differs according to bank characteristics. Distinguin et al. (2013) suggest that the ratio of interbank deposits to total deposits (BDTD) might be regarded as a market discipline factor. For the same sample of countries over the period from 1995 to 2006, these authors find that higher proportions of deposits from other banks to total deposits reduce the bank risk, as measured by the standard deviation of returns on equity and assets, in addition to the traditional Z-score. Our results do not confirm these findings neither with market-based risk measures nor with Z-score indicator used by Dinstinguin et al. (20103). 
However, with our improved Zscore1 we find effectively that banks with higher proportions of interbank deposits to total deposits are better capitalised. Thus, banks offer their excess of liquidity only to their counterparts that are well capitalised with respect to return distribution. Well capitalised banks are also preferred by long-term investors. The ratio of long-term funding of bank activities to total funds (LTFTF) has a positive effect on Zscore1 but also on Zscore3. On the other hand, the market perception of the bank risk is not influenced by the funding structure of bank activities as well by the banks' business model. The ratio of interest income to total operating income (IIOI) has a negative effect only on Zscore1, which doubles for model (b). Concentrating on interest-bearing activities is associated with lower capitalisation for banks, but this does not affect the global market perception of risk.

The country’s environment also affects the bank risk, but this is not revealed by all risk measures. The banking regulatory environment indicator (BRI) is statistically significant only for the accounting-based measures and it indicates that more restrictive banking regulatory environments are associated with lower bank risk. This result does not corroborate the findings of Barth et al. (2001, 2004) and González (2005) but it is consistent with those of Klomp and De Haan (2012). With respect to Z-scores, this is most likely because enforcing the regulation in CEE countries constrains banks to increase their capitalisation and thus it reduces the probability of default. As for the annual growth rate of the real Gross Domestic Product (RGDPG), it influences only DD_KMV and Zscore3. The market perceives banks as less risky during the economic growth and throughout this period the returns on assets are less erratic, their standard deviation lower and Zscore3 higher.

To summarise, our findings clearly show that ownership influences the risk profile of CEE banks, depicted either with market-based measures or with accounting-based ones. Foreign banks are the least risky and the state-owned institutions the most risky, result obtained with the Distance to Default and Zscore1 measures. Other bank characteristics, in 
addition to country-specific features, are related to bank risk as expected; but their impact might be different according to bank ownership structure. More precisely, the type of funding for bank activities, whether interbank deposits or long-term funds, might not have the same effects on the default probabilities of foreign, private and state-owned banking institutions. Lack of diversification in banking activities and concentration on interest-bearing ones might also have different effects on banks' risk according to their ownership structure. Finally, as previously found, tightening of the banking regulation generally reduces the risk-taking behaviour but we expect that this effect might be different for foreign, private and stateowned banks.

4.4 Is there a difference between foreign, private and state-owned banks in terms of the effects of certain bank- and country-specific characteristics on risk?

Our key findings clearly indicate that foreign banks are the least risky and the stateowned banks are the most risky institutions and that bank- and country-specific characteristics affect the banks' risk. In this point, we extend our analysis and examine whether the sources of bank funding, bank diversification and banking regulation have different effects on foreign, private and state-owned banks.

\subsubsection{Sources of bank activity funding}

We now test whether there are differences in the effects of interbank deposits and longterm funds on foreign, private and state-owned banks. To this end, we interact the bank activity funding indicators (BDTD and LTFTF) with the ownership dummy variables (FOR and PRIV). The results for all models and all measures of risk are presented in table 3 and show that a higher proportion of interbank deposits to total deposits makes foreign banks riskier from the market point of view, model (a). On the other hand, the market perception of 
the private and public banks' risk is not affected by changes to the interbank deposits ratio. As for accounting-based measures, the results for Zscore1 confirm our previous ones but only for state-owned banks: their counterparts offer them their excess of liquidity only if they are sufficiently well capitalised.

Thus, we conclude that interbank deposits increase the risk of foreign institutions from the market point of view and have no effect on private and state-owned banks. Because foreign institutions have the highest proportions of interbank deposits, they are also susceptible to substantial liquidity problems when the financial and economic environment worsens. On the other hand, from the accounting point of view the interbank deposits reduce only the risk of state-owned banks that improve their capitalisation and thus obtain more liquid deposits from their counterparts.

With regard to the ratio of long-term funds to total funds, state-owned banks are considered by the market as riskier, model (b). We suppose that CEE markets do not have confidence in the capacity of state-owned banking institutions to respect their indebtedness commitments, which is realistic for these countries; the government has insufficient resources to rescue the banks it owns because of their large sizes. Conversely, the ratio of long-term funds has no effect on the risk of foreign and domestic private banks. As for accounting-based risk measures, they provide an opposite result confirming the previous global finding only for the public banks. The ratio of long-term funds to total funds reduces the risk of these institutions because they improve their capitalisation level.

\subsubsection{Bank activity diversification}

We also found that by diversifying their activities and reducing their concentration on interest-bearing ones, CEE banks reduce their risk from the accounting point of view. 
However, are there any differences among foreign, private and state-owned banking institutions?

To answer this question, we include two cross-product terms in our regressions: the ratio of interest income to total operating income interacted with the foreign ownership dummy variable (IIOI*FOR) and the private ownership dummy variable (IIOI*PRIV). The results presented in table 4 confirm our hypothesis of ownership implication on the effect of bank activity diversification. Indeed, for both models (a) and (b) the ratio of interest income to total operating income has a negative effect on Zscore1 for all types of banks, but with different magnitude. The bank activity diversification reduces this accounting-based measure of risk at most for foreign banks and at least for public banks if we consider the model (a), and there is no ownership difference if the model (b) is examined.

Contrary to Zscore1, as for the global effect regression the Distance to Default does not change with the indicator of bank activity diversification regardless the ownership structure, the market being not sensitive to the business model of CEE banks.

\subsubsection{Banking regulation}

We will now explore the differences in the effects of banking regulation. As explained above, the strengthening of the banking regulation reduces the overall risk of banks considered with accounting-based measures, but the probability of default may vary according to ownership structure. In this pont, we test whether foreign and private banks are always less risky than state-owned institutions in countries with more restrictive banking regulation or whether the tightening of the regulation reduces the risk of all banks uniformly.

As in the previous analyses, we introduce two cross-product terms in all regressions; specifically, we introduce the banking regulation index interacted with the foreign ownership dummy variable (BRI*FOR) and the private ownership dummy variable (BRI*PRIV). The 
results, presented in table 5, are interesting. The coefficient that describes the effectiveness of banking regulation on the reduction of the risk of foreign banks is not only statistically significant for all specifications and all risk measures but also economically noteworthy. By contrast, changes in the banking regulatory environment do not affect the risk of private banks and have an opposite effect on that of public institutions with respect to the type of risk measure considered.

How to explain these very different results? From the market point of view, we confirm the results of Barth et al. (2001, 2004) and (González, 2005) but only for state-owned banks and those of Klomp and De Haan (2012) for foreign banks. The enforcement of the banking regulation constrains the banking institutions to improve their management practices, asset quality, liquidity and prudential ratios (see Appendix A for more details) and, generally, enforces them to follow banking practices and standards from developed countries. For these reasons and because foreign banks are typically from countries with well-developed banking markets, the enforcement of the banking regulation will reduce the risk of these institutions. Indeed, the market considers them the least risky because they are already or can very easily be adapted to new more tightening regulatory environment. It is not the case for public banks, because in these countries the government has insufficient resources to prepare them adequately to the banking regulatory enforcement. This is probably why the tightening of the banking regulation decreases their Distance to Default. As for private banks, there are many factors that can compensate the different effects of the regulation. In CEE countries, these banks are among the smallest banking institutions and some of them could not comply with new regulatory requirements. On the other hand, the enforcement of the banking regulation reduces competition, diminishing the probability of acquisition of smaller banking institutions by larger banks (Struck and Mandell, 1983) and, in this way, the probability of default of smallest banks. 


\section{Robustness checks}

To check our results and confirm our conclusions, we conduct our estimations again, adjusting certain variables.

First, we refine our analyses with respect to Banking Regulation Index. We consider its two components, the Barriers to Entry Index (BEI) and Stability Regulation Index (SRI) (see Appendix A), separately. The first results, presented in Appendix B, are similar to our previous findings and do not change our main conclusion that foreign and private banks are less risky than state-owned institutions. Regarding whether there are differences among foreign, private and state-owned banking institutions in relation to the effects of some bankand country-specific characteristics on the risk, our conclusions are also consistent. ${ }^{4} \mathrm{~A}$ small difference is for stability regulation index that reduces the CEE banks' risk through the Distance to Default.

Second, we re-estimate our market-based risk measure with a twelve-month rolling window. The Distance to Default shows the same trend but the magnitude of variations differs. Consequently, our conclusions from previous findings are consistent. ${ }^{5}$

\section{Conclusions}

Since the late 1980, the new EU member states have implemented many reforms in banking that have profoundly changed the practices and the risk-taking behaviour of their banks. Many state-owned institutions have been privatised and many others, namely foreign banks, entered into these markets. Given the different practices of these banks according to their ownership profile, their risk-taking behaviour might, in consequence, be also different. Our main research issues that have been addressed within this paper are the difference in risk

\footnotetext{
${ }^{4}$ Results are available upon request.

${ }^{5}$ Results are available upon request.
} 
between foreign, private and state-owned banks of new EU member states and the reasons of such difference from the point of view of bank activity and regulation.

By controlling for different factors, our main results indicate that foreign and domestic private banks are less risky than state-owned institutions. This market perception is most likely caused by better management by private and foreign investors than by public institutions. Despite implicit insurance from the government, the non-commercial and policyoriented practices of CEE state-owned banks make the market "worry" about their performance. In addition, it is unlikely that CEE governments could rescue their state-owned banks during crises because of the size of such banks. This result is also obtained with the improved Z-score measure.

Considering the effects of certain bank- and country-specific characteristics, we find that a higher proportion of interbank deposits increases the risk of foreign banks but has no effect on private and state-owned institutions. This result is most likely because foreign banks have the highest proportions of interbank deposits, which make them riskier in terms of liquidity. It is not the case from the accounting point of view, because the public banks increase their capitalisation level and thus obtain more liquid deposits from their counterparts but also more long-term funds. However, the market perceives these banks as more risky with the increase of the proportion of long-term funds.

We also find that the concentration on interest-bearing activities greatly increases the risk of all banks, regardless their ownership structure, and the enforcement of the banking regulation reduces the risk of foreign banks and increases that of public institutions. It is probably due the obligation of banks to improve their management practices, asset quality, liquidity and prudential ratios and only the foreign banks are already or can very easily be adapted to new more tightening regulatory environment. Because of insufficient resources, the public banks cannot easily comply with new regulatory requirements. 


\section{Appendix A}

This appendix provides details about the coverage and construction of the banking regulatory indicators used in the empirical analysis. Data come from four Bank Regulation and Supervision Data bases from the World Bank, elaborated by Barth, Caprio and Levine (2000, 2003, 2007, 2012). These databases consist of approximately 300 questions divided into 12 sub-groups, each of which corresponds to specific aspects of banking regulation and supervision, namely entry requirements into banking, ownership structure, capital adequacy, banking activity, external auditing requirements, internal management and organisational requirements, liquidity and diversification requirements, depositor protection, provisioning requirements, accounting and information disclosure requirements, discipline and problem institutions exit, and supervisory structure.

Many questions in the surveys require yes/no answers. We assigned a value of 1 to those that involve the enforcement of different aspects of the banking regulation, and 0 otherwise. We then aggregated the answers relevant to each of our 14 indicators $\operatorname{IND} D_{i}(i=1, \ldots, 14)$. Three of them correspond to the Barriers to Entry index (BEI): overall entry index (0.4), foreign entry index (0.4) and permission activity index (0.2). The others correspond to the Stability Regulation Index (SRI): capital adequacy (0.2), activity diversification (0.05), liquidity (0.175), provisioning (0.175), deposit insurance (DI, 0.175), accounting standards (0.05), auditing requirements (0.025), internal management (0.025), ownership (0.05), discipline and enforcement (0.05) and supervisory structure (0.25). To make each of these 14 indicators comparable across countries and years, they are normalised with the formula $\overline{I N D}_{i, t}=$ $\left(I N D_{i, t}-\min _{i, t} I N D_{i, t}\right) /\left(\max _{i, t} I N D_{i, t}-\min _{i, t} I N D_{i, t}\right)$ and range in values between 0 and

1. The weights of the indicators in the composition of the Barriers to Entry Index and Stability Regulation Index are presented in parentheses, and BEI and SRI are equally weighted in the composition of the Banking Regulation Index (BRI). 
Appendix B 


\section{References}

Barth, J.R., Caprio, G. Jr. and Levine, R. (2001). 'Banking systems around the globe: Do regulations and ownership affect performance and stability?' In: Mishkin F. (Eds.), Prudential Supervision: What Works and What Doesn't. University of Chicago Press, Chicago, pp. 31-95.

Barth, J.R., Caprio, G. Jr. and Levine, R. (2004). 'Bank regulation and supervision: what works best?', Journal of Financial Intermediation, 13, pp. 205-248.

Berger, A.N. (1995). 'The relationship between capital and earnings in banking', Journal of Money, Credit and Banking, 27, pp. 432-456.

Black, F., Scholes, M. (1973). 'The pricing of options and corporate liabilities', Journal of Political Economy, 8, pp. 1637-1659.

Bonin, J.P., Mizsei, K., Székely, I.P. and Wachtel, P. (1998). Banking in Transition Economies: Developing Market Oriented Banking Sectors in Eastern Europe. Cheltenham, UK - Northampton, Edward Elgar, MA, USA.

Boyd, J.H., Runkle, D.E. (1993). 'Size and performance of banking firms', Journal of Monetary Economics, 31, pp. 47-67.

Boyd, J.H., Graham, S.L. and Hewitt, S.R. (1993). 'Bank holding company mergers with nonbank financial firms: effects on the risk of failure', Journal of Banking and Finance, 17, pp. 43-63.

Chou, S., Lin, F. (2011). 'Bank’s risk-taking and ownership structure - evidence for economics in transition stage’, Applied Economics, 43, pp. 1551-1564.

De Haas, R., Ferreira, D. and Taci, A. (2010). 'What determines the composition of banks' loan portfolios? Evidence from transition countries', Journal of Banking and Finance, 34, pp. 388-398. 
Demirgüc-Kunt, A., Detragiache, E. (2002). 'Does deposit insurance increase banking system stability? An empirical investigation', Journal of Monetary Economics, 49, pp. 1373-1406.

Distinguin, I., Kouassi, T. and Tarazi, A. (2013). 'Interbank deposits and market discipline: Evidence from Central and Eastern Europe', Journal of Comparative Economics, 41, pp. 544-560.

Duan, J.C. (1994). 'Maximum likelihood estimation using price data of the derivative contract', Mathematical Finance, 4, pp. 155-167.

Duan, J.C. (2000). 'Correction: Maximum likelihood estimation using price data of the derivative contract', Mathematical Finance, 10, pp. 461-462.

Duan, J.C., Gauthier, G. and Simonato, J.G. (2005). 'On the equivalence of the KMV and Maximum Likelihood methods for structural credit risk models’. June 15, mimeo.

Duan, J.C., Yu, M.T. (1994). 'Forbearance and pricing deposit insurance in a multiperiod framework', Journal of Risk and Insurance, 61, pp. 575-591.

Faccio, M., Masulis, R.W. and McConnell, J.J. (2006). 'Political connections and corporate bailouts', The Journal of Finance, 61, pp. 2597-2635.

González, F. (2005). 'Bank regulation and risk-taking incentives: An international comparison of bank risk', Journal of Banking and Finance, 29, pp. 1153-1184.

Hannan, T.H., Hanweck, G.A. (1988). 'Bank insolvency risk and the market for large certificates of deposit', Journal of Money, Credit and Banking, 20, pp. 203-211.

Iannotta, G., Nocera, G. and Sironi, A. (2007). 'Ownership structure, risk and performance in the European banking industry’, Journal of Banking and Finance, 31, pp. 2127-2149.

Iannotta, G., Nocera, G. and Sironi, A. (2013). 'The impact of government ownership on bank risk’, Journal of Financial Intermediation, 22, pp. 152-176.

Klomp, J., De Haan, J. (2012). 'Banking risk and regulation: Does one size fit all?', Journal of Banking and Finance, 36, pp. 3197-3212. 
Laeven, L. (1999). 'Risk and Efficiency in East Asian Banks'. World Bank, Discussion Paper No. 2255.

Laeven, L. (2002). 'Bank risk and deposit insurance', World Bank Economic Review, 16, pp. 109-137.

Lehar, A. (2005). 'Measuring systemic risk: A risk management approach', Journal of Banking and Finance, 29, pp. 2577-2603.

Merton, R.C. (1974). 'On the pricing of corporate debt: the risk structure of interest rates', Journal of Finance, 28, pp. 449-470.

Merton, R.C. (1977). 'An analytical derivation of the cost of deposit insurance and loan guarantees’, Journal of Banking and Finance, 1, pp. 3-11.

Nier, E., Baumann, U. (2006). 'Market discipline, disclosure and moral hazard in banking', Journal of Financial Intermediation, 15, pp. 332-361.

Organisation for Economic Co-operation and Development (OECD) (1996). Romanian Restructuring of the Banking Sector. OECD, Paris.

Ronn, E.I., Verma, A.K. (1986). 'Pricing risk-adjusted deposit insurance: an option-based model', Journal of Finance, 41, pp. 871-895.

Shleifer, A. (1998). 'State versus private ownership', Journal of Economic Perspectives, 12, pp. 133-150.

Shleifer, A., Vishny, R.W. (1986). 'Large shareholders and corporate control', Journal of Political Economy, 94, pp. 461-488.

Struck, P.L., Mandell, L. (1983). 'The Effect of Bank Deregulation on Small Business: A Note’, Journal of Finance, 38, pp. 1025-1031.

Vassalou, M., Xing, Y. (2004). 'Default risk in equity returns', Journal of Finance, 59, pp. 831-868. 
TABLE 1. Risk estimates and their evolution.

\begin{tabular}{|c|c|c|c|c|c|c|c|c|c|c|c|c|c|c|c|c|c|c|c|}
\hline $\begin{array}{l}\text { Country/ } \\
\text { Risk measure }\end{array}$ & $\begin{array}{c}199 \\
5\end{array}$ & $\begin{array}{c}199 \\
6 \\
\end{array}$ & $\begin{array}{c}199 \\
7\end{array}$ & $\begin{array}{c}199 \\
8 \\
\end{array}$ & $\begin{array}{c}199 \\
9 \\
\end{array}$ & $\begin{array}{c}200 \\
0\end{array}$ & $\begin{array}{c}200 \\
1\end{array}$ & $\begin{array}{c}200 \\
2\end{array}$ & $\begin{array}{c}200 \\
3\end{array}$ & $\begin{array}{c}200 \\
4\end{array}$ & $\begin{array}{c}200 \\
5\end{array}$ & $\begin{array}{c}200 \\
6\end{array}$ & $\begin{array}{c}200 \\
7\end{array}$ & $\begin{array}{c}200 \\
8\end{array}$ & $\begin{array}{c}200 \\
9\end{array}$ & $\begin{array}{c}201 \\
0\end{array}$ & $\begin{array}{c}201 \\
1\end{array}$ & $\begin{array}{c}201 \\
2\end{array}$ & $\begin{array}{c}201 \\
3\end{array}$ \\
\hline \multicolumn{20}{|l|}{ Bulgaria } \\
\hline Zscore1 & 10.52 & 20.91 & 14.21 & 16.06 & 15.34 & 18.46 & 15.53 & 13.80 & 12.89 & 12.10 & 10.71 & 8.99 & 8.88 & 10.43 & 11.52 & 10.75 & 10.30 & 10.79 & 10.81 \\
\hline Zscore2 & 13.35 & 24.16 & 16.96 & 20.49 & 19.63 & 24.19 & 19.24 & 16.76 & 15.19 & 14.10 & 12.58 & 10.59 & 9.92 & 12.29 & 13.84 & 12.76 & 12.02 & 12.71 & 13.06 \\
\hline Zscore3 & - & - & 2.57 & 4.97 & 3.68 & 19.87 & 28.95 & 66.89 & 61.02 & 42.86 & 43.47 & 37.13 & 37.69 & 114.7 & 45.01 & 33.79 & 74.60 & 32.26 & 40.06 \\
\hline DD_KMV & - & - & - & - & - & - & - & - & - & - & - & 8.13 & 6.82 & 1.31 & 0.44 & 2.05 & 3.21 & 4.38 & 3.70 \\
\hline DD_Duan & - & - & - & - & - & - & - & - & - & - & - & 8.16 & 6.80 & 1.31 & 0.48 & 1.95 & 2.80 & 3.83 & 3.07 \\
\hline \multicolumn{20}{|l|}{ Czech Rep. } \\
\hline Zscore1 & 12.97 & 22.50 & 21.30 & 18.25 & 17.38 & 14.68 & 17.02 & 18.60 & 16.17 & 15.89 & 16.11 & 15.53 & 15.24 & 15.98 & 16.23 & 17.54 & 16.99 & 17.12 & 16.23 \\
\hline Zscore2 & 15.58 & 31.57 & 21.47 & 22.87 & 20.64 & 17.83 & 19.23 & 19.33 & 18.50 & 18.85 & 19.39 & 18.34 & 16.87 & 17.44 & 18.30 & 19.82 & 19.44 & 19.83 & 19.18 \\
\hline Zscore3 & - & - & 34.73 & 30.23 & 23.32 & 13.25 & 20.75 & 40.62 & 31.70 & 74.34 & 43.52 & 50.76 & 67.35 & 44.91 & 105.4 & 45.66 & 70.48 & 57.46 & 74.90 \\
\hline DD_KMV & - & 4.49 & -1.77 & -1.39 & -1.86 & 1.04 & 4.42 & 6.30 & 6.01 & 5.74 & 4.40 & 4.80 & 6.56 & 1.96 & 2.16 & 3.11 & 3.27 & 3.77 & 5.38 \\
\hline DD_Duan & - & 4.39 & -1.50 & -1.27 & -1.46 & 1.05 & 4.49 & 6.12 & 6.01 & 5.77 & 4.42 & 4.82 & 6.49 & 1.99 & 2.16 & 3.16 & 3.29 & 3.81 & 5.41 \\
\hline \multicolumn{20}{|l|}{ Hungary } \\
\hline Zscore1 & 9.14 & 9.02 & 9.44 & 10.21 & 9.81 & 10.40 & 10.02 & 9.87 & 9.18 & 9.36 & 9.28 & 13.45 & 9.66 & 8.88 & 9.62 & 9.61 & 8.97 & 9.37 & 9.30 \\
\hline Zscore2 & 11.81 & 11.28 & 11.99 & 12.16 & 11.52 & 12.52 & 12.34 & 12.02 & 11.02 & 11.70 & 11.37 & 16.85 & 11.94 & 10.93 & 12.09 & 12.47 & 11.47 & 12.18 & 12.31 \\
\hline Zscore3 & - & - & 29.55 & 12.87 & 63.29 & 24.17 & 22.98 & 42.27 & 52.49 & 37.27 & 55.13 & 86.00 & 41.38 & 42.88 & 23.46 & 30.90 & 26.14 & 23.98 & 19.59 \\
\hline DD_KMV & - & 0.88 & 0.84 & 2.20 & 1.39 & 2.09 & 3.74 & 5.69 & 6.09 & 7.38 & 5.31 & 3.64 & 6.10 & 1.05 & 1.92 & 0.83 & 1.02 & 1.74 & 3.19 \\
\hline DD_Duan & - & 0.80 & 0.80 & 2.23 & 1.38 & 2.11 & 3.78 & 5.64 & 6.11 & 7.40 & 5.33 & 3.65 & 6.13 & 1.05 & 1.81 & 0.84 & 1.03 & 1.76 & 3.23 \\
\hline \multicolumn{20}{|l|}{ Estonia } \\
\hline Zscore1 & 13.96 & 10.88 & 6.31 & 9.34 & 9.79 & 8.99 & 8.91 & 8.95 & 9.08 & 9.59 & 8.84 & 8.25 & 7.89 & 7.80 & 7.12 & 7.98 & 8.95 & 10.07 & 10.29 \\
\hline Zscore2 & 17.46 & 14.78 & 8.06 & 13.37 & 13.96 & 12.13 & 11.81 & 12.27 & 12.61 & 13.89 & 12.62 & 11.21 & 10.54 & 9.96 & 9.06 & 10.55 & 12.42 & 14.38 & 14.61 \\
\hline Zscore3 & - & - & 10.11 & 4.55 & 4.37 & 4.63 & 19.90 & 34.79 & 95.88 & 132.8 & 50.93 & 43.02 & 61.20 & 25.32 & 2.62 & 3.67 & 3.77 & 21.95 & 30.82 \\
\hline DD_KMV & - & - & - & - & - & - & - & - & - & - & - & - & - & - & - & - & - & - & - \\
\hline DD_Duan & - & - & - & - & - & - & - & - & - & - & - & - & - & - & - & - & - & - & - \\
\hline
\end{tabular}


TABLE 1. (continued)

\begin{tabular}{|c|c|c|c|c|c|c|c|c|c|c|c|c|c|c|c|c|c|c|c|}
\hline $\begin{array}{l}\text { Country/ } \\
\text { Risk measure }\end{array}$ & $\begin{array}{c}199 \\
5\end{array}$ & $\begin{array}{c}199 \\
6 \\
\end{array}$ & $\begin{array}{c}199 \\
7\end{array}$ & $\begin{array}{c}199 \\
8 \\
\end{array}$ & $\begin{array}{c}199 \\
9 \\
\end{array}$ & $\begin{array}{c}200 \\
0\end{array}$ & $\begin{array}{c}200 \\
1\end{array}$ & $\begin{array}{c}200 \\
2\end{array}$ & $\begin{array}{c}200 \\
3\end{array}$ & $\begin{array}{c}200 \\
4\end{array}$ & $\begin{array}{c}200 \\
5\end{array}$ & $\begin{array}{c}200 \\
6\end{array}$ & $\begin{array}{c}200 \\
7\end{array}$ & $\begin{array}{c}200 \\
8 \\
\end{array}$ & $\begin{array}{c}200 \\
9\end{array}$ & $\begin{array}{c}201 \\
0\end{array}$ & $\begin{array}{c}201 \\
1\end{array}$ & $\begin{array}{c}201 \\
2 \\
\end{array}$ & $\begin{array}{c}201 \\
3 \\
\end{array}$ \\
\hline \multicolumn{20}{|l|}{ Latvia } \\
\hline Zscore1 & 41.05 & 9.51 & 11.39 & 11.00 & 9.62 & 7.50 & 9.53 & 7.59 & 7.69 & 7.05 & 7.51 & 6.95 & 6.85 & 7.19 & 7.24 & 6.77 & 8.10 & 9.84 & 9.49 \\
\hline Zscore2 & 66.09 & 12.47 & 13.92 & 13.19 & 11.19 & 8.51 & 12.11 & 8.96 & 9.34 & 8.14 & 8.94 & 8.18 & 8.02 & 8.15 & 8.19 & 7.47 & 8.51 & 10.19 & 10.09 \\
\hline Zscore3 & - & - & 13.76 & 3.88 & 10.33 & 10.34 & 18.08 & 32.11 & 35.79 & 52.13 & 36.23 & 27.56 & 28.49 & 20.47 & 10.31 & 18.81 & 12.94 & 12.84 & 27.88 \\
\hline DD_KMV & - & - & - & - & - & - & - & - & - & - & - & - & - & - & - & - & - & - & - \\
\hline DD_Duan & - & - & - & - & - & - & - & - & - & - & - & - & - & - & - & - & - & - & - \\
\hline \multicolumn{20}{|l|}{ Lithuania } \\
\hline Zscore1 & 7.86 & 15.69 & 13.67 & 17.94 & 18.05 & 15.01 & 12.91 & 12.21 & 11.73 & 9.97 & 9.60 & 8.62 & 9.31 & 10.22 & 9.59 & 8.76 & 10.12 & 11.32 & 10.74 \\
\hline Zscore2 & 10.01 & 21.09 & 18.93 & 25.08 & 25.42 & 21.12 & 18.14 & 16.95 & 16.06 & 13.38 & 12.68 & 11.16 & 12.07 & 14.08 & 13.15 & 11.98 & 13.73 & 15.37 & 14.40 \\
\hline Zscore3 & - & - & 5.74 & 20.16 & 38.02 & 32.12 & 52.01 & 37.37 & 77.15 & 76.17 & 64.41 & 52.07 & 39.44 & 33.08 & 6.69 & 4.62 & 4.54 & 7.75 & 63.08 \\
\hline DD_KMV & - & - & - & 0.30 & 2.34 & 2.29 & 3.61 & 3.79 & 4.55 & 4.87 & 5.98 & 3.21 & 5.33 & 0.38 & 0.49 & 3.42 & 2.02 & 2.28 & 3.62 \\
\hline DD_Duan & - & - & - & 0.32 & 2.33 & 2.27 & 3.28 & 3.03 & 3.82 & 4.51 & 5.87 & 2.89 & 4.83 & 0.39 & 0.41 & 3.37 & 2.08 & 2.16 & 1.80 \\
\hline \multicolumn{20}{|l|}{ Poland } \\
\hline Zscore1 & 13.01 & 13.25 & 13.47 & 13.41 & 12.80 & 16.73 & 12.83 & 12.54 & 11.82 & 11.71 & 11.09 & 11.76 & 11.38 & 10.65 & 11.05 & 11.55 & 11.51 & 12.28 & 12.28 \\
\hline Zscore2 & 16.32 & 16.67 & 17.41 & 17.21 & 16.34 & 21.94 & 16.18 & 15.70 & 14.52 & 14.06 & 13.13 & 14.02 & 13.29 & 12.20 & 13.02 & 13.54 & 13.37 & 14.49 & 14.72 \\
\hline Zscore3 & - & - & 20.89 & 17.51 & 27.00 & 31.72 & 23.11 & 27.64 & 30.24 & 27.81 & 28.73 & 47.67 & 35.66 & 39.03 & 44.42 & 36.46 & 43.56 & 88.06 & 72.70 \\
\hline DD_KMV & - & 4.07 & 1.23 & 2.27 & 2.49 & 2.34 & 3.78 & 3.42 & 3.95 & 5.02 & 4.26 & 5.09 & 4.71 & 1.82 & 1.64 & 3.14 & 2.04 & 3.02 & 4.64 \\
\hline DD_Duan & - & 3.69 & 1.20 & 2.06 & 2.30 & 2.14 & 3.45 & 3.37 & 3.77 & 4.56 & 4.24 & 4.99 & 4.52 & 1.70 & 1.45 & 3.06 & 2.03 & 2.87 & 4.43 \\
\hline \multicolumn{20}{|l|}{ Romania } \\
\hline Zscore1 & 11.40 & 15.93 & 9.44 & 11.63 & 10.34 & 10.98 & 10.00 & 9.54 & 8.88 & 8.25 & 8.00 & 7.82 & 7.23 & 7.39 & 6.79 & 7.40 & 7.62 & 7.41 & 7.29 \\
\hline Zscore2 & 10.94 & 21.28 & 10.82 & 14.08 & 12.06 & 13.46 & 11.68 & 10.79 & 9.78 & 8.92 & 8.69 & 8.62 & 7.88 & 8.01 & 7.43 & 8.06 & 8.56 & 8.41 & 8.13 \\
\hline Zscore3 & - & - & 4.92 & 5.88 & 11.61 & 15.21 & 25.33 & 11.46 & 46.35 & 23.41 & 25.34 & 23.16 & 22.79 & 25.38 & 20.12 & 15.47 & 22.16 & 26.56 & 29.53 \\
\hline DD_KMV & - & - & - & 1.71 & 0.36 & 1.91 & 1.57 & 3.56 & 5.61 & 6.05 & 5.34 & 6.04 & 4.87 & 0.20 & 1.18 & 0.98 & 3.08 & 2.82 & 3.80 \\
\hline DD_Duan & - & - & - & 1.31 & 0.33 & 1.40 & 1.47 & 3.51 & 5.59 & 5.89 & 5.27 & 6.03 & 4.80 & 0.20 & 0.88 & 1.05 & 2.95 & 2.42 & 3.85 \\
\hline
\end{tabular}


TABLE 1. (continued)

\begin{tabular}{|c|c|c|c|c|c|c|c|c|c|c|c|c|c|c|c|c|c|c|c|}
\hline $\begin{array}{l}\text { Country/ } \\
\text { Risk measure }\end{array}$ & $\begin{array}{c}199 \\
5 \\
\end{array}$ & $\begin{array}{c}199 \\
6 \\
\end{array}$ & $\begin{array}{c}199 \\
7 \\
\end{array}$ & $\begin{array}{c}199 \\
8 \\
\end{array}$ & $\begin{array}{c}199 \\
9 \\
\end{array}$ & $\begin{array}{c}200 \\
0 \\
\end{array}$ & $\begin{array}{c}200 \\
1 \\
\end{array}$ & $\begin{array}{c}200 \\
2 \\
\end{array}$ & $\begin{array}{c}200 \\
3 \\
\end{array}$ & $\begin{array}{c}200 \\
4 \\
\end{array}$ & $\begin{array}{c}200 \\
5 \\
\end{array}$ & $\begin{array}{c}200 \\
6 \\
\end{array}$ & $\begin{array}{c}200 \\
7 \\
\end{array}$ & $\begin{array}{c}200 \\
8 \\
\end{array}$ & $\begin{array}{c}200 \\
9 \\
\end{array}$ & $\begin{array}{c}201 \\
0 \\
\end{array}$ & $\begin{array}{c}201 \\
1 \\
\end{array}$ & $\begin{array}{c}201 \\
2 \\
\end{array}$ & $\begin{array}{c}201 \\
3 \\
\end{array}$ \\
\hline \multicolumn{20}{|l|}{ Slovakia } \\
\hline Zscore1 & 14.51 & 12.73 & 12.89 & 15.07 & 15.13 & 16.48 & 13.22 & 13.34 & 14.26 & 13.38 & 12.83 & 12.78 & 12.83 & 12.46 & 13.48 & 12.96 & 13.95 & 14.77 & 14.44 \\
\hline Zscore2 & 23.84 & 18.30 & 18.35 & 21.10 & 22.10 & 24.46 & 19.23 & 19.50 & 21.35 & 19.79 & 18.80 & 18.91 & 18.82 & 18.18 & 20.40 & 19.35 & 21.14 & 22.50 & 21.96 \\
\hline Zscore3 & - & - & 56.32 & 39.22 & 25.66 & 25.30 & 23.28 & 36.08 & 66.58 & 40.74 & 78.82 & 98.56 & 109.6 & 56.43 & 54.63 & 36.34 & 41.85 & 42.42 & 59.76 \\
\hline DD_KMV & - & - & - & -3.05 & -3.85 & -1.04 & -1.63 & 1.22 & 3.79 & 3.77 & 1.08 & 3.79 & 4.27 & 3.32 & -1.06 & -0.80 & 0.78 & 2.03 & 3.21 \\
\hline DD_Duan & - & - & - & -2.81 & -2.90 & -0.86 & -1.23 & 0.12 & 1.96 & 1.73 & 0.81 & 2.90 & 2.85 & 2.85 & -0.94 & -0.74 & 0.89 & 1.68 & 2.42 \\
\hline \multicolumn{20}{|l|}{ Slovenia } \\
\hline Zscore1 & 15.15 & 11.00 & 20.29 & 18.15 & 17.29 & 15.97 & 14.03 & 11.94 & 11.11 & 10.81 & 10.60 & 9.99 & 9.32 & 9.05 & 9.46 & 9.23 & 9.16 & 8.81 & 8.58 \\
\hline Zscore2 & 19.28 & 14.56 & 32.11 & 28.28 & 26.98 & 24.68 & 21.13 & 17.11 & 15.64 & 14.99 & 15.09 & 13.87 & 12.85 & 12.35 & 13.12 & 12.70 & 12.62 & 12.23 & 12.29 \\
\hline Zscore3 & - & - & 66.69 & 65.16 & 103.8 & 161.5 & 122.2 & 81.23 & 120.2 & 38.13 & 38.46 & 40.97 & 45.51 & 38.67 & 32.28 & 44.06 & 37.21 & 37.88 & 33.14 \\
\hline DD_KMV & - & - & - & - & - & - & - & - & - & - & - & 3.27 & 3.44 & 0.57 & 3.37 & 0.04 & -2.13 & -3.46 & -3.33 \\
\hline DD_Duan & - & - & - & - & - & - & - & - & - & - & - & 1.07 & 1.21 & 0.13 & 2.76 & 0.11 & -1.76 & -3.04 & -3.14 \\
\hline \multicolumn{20}{|l|}{ Global } \\
\hline \multicolumn{20}{|l|}{ Zscore1 } \\
\hline FOR & 10.71 & 13.83 & 10.15 & 12.46 & 11.41 & 11.66 & 11.68 & 11.95 & 11.04 & 10.65 & 10.06 & 10.18 & 9.15 & 9.31 & 9.61 & 9.75 & 10.36 & 10.99 & 10.91 \\
\hline PRIV & 14.63 & 11.86 & 11.17 & 12.43 & 12.11 & 11.98 & 11.34 & 11.24 & 10.02 & 9.77 & 9.53 & 9.60 & 10.23 & 9.99 & 10.58 & 10.43 & 9.62 & 9.88 & 9.41 \\
\hline STATE & 12.36 & 13.10 & 12.00 & 11.40 & 15.27 & 15.28 & 14.47 & 14.23 & 13.50 & 12.60 & 14.45 & 15.19 & 14.73 & 14.56 & 14.48 & 13.89 & 13.30 & 13.99 & 13.86 \\
\hline \multicolumn{20}{|l|}{ Zscore3 } \\
\hline FOR & - & - & 24.99 & 16.32 & 30.11 & 16.89 & 22.88 & 30.40 & 33.54 & 39.74 & 38.58 & 51.76 & 43.55 & 36.21 & 33.63 & 27.51 & 43.21 & 41.37 & 50.13 \\
\hline PRIV & - & - & 21.08 & 17.47 & 22.97 & 23.63 & 30.82 & 43.53 & 66.41 & 67.09 & 38.10 & 33.46 & 37.28 & 65.41 & 47.55 & 31.59 & 22.81 & 25.93 & 26.46 \\
\hline STATE & - & - & 44.75 & 33.66 & 49.69 & 69.50 & 55.84 & 65.42 & 123.4 & 42.61 & 73.43 & 71.32 & 73.29 & 64.25 & 50.27 & 36.86 & 31.48 & 62.64 & 61.86 \\
\hline \multicolumn{20}{|l|}{ DD_KMV } \\
\hline FOR & - & 3.89 & 1.30 & 2.82 & 2.68 & 2.13 & 2.86 & 3.47 & 4.27 & 5.23 & 3.95 & 4.92 & 5.05 & 1.88 & 0.97 & 1.81 & 1.92 & 2.69 & 4.27 \\
\hline$P R I V$ & - & 3.17 & 0.87 & 1.57 & 2.05 & 2.06 & 3.91 & 4.13 & 4.69 & 5.32 & 5.81 & 4.47 & 4.86 & 0.84 & 1.43 & 2.01 & 1.68 & 2.15 & 2.14 \\
\hline STATE & - & 4.21 & 0.59 & 0.36 & -0.44 & 1.18 & 2.10 & 2.32 & 5.35 & 3.98 & 4.27 & 4.88 & 5.24 & 1.58 & 2.57 & 1.94 & -0.54 & -0.60 & 1.75 \\
\hline \multicolumn{20}{|l|}{ DD_Duan } \\
\hline FOR & - & 3.87 & 1.30 & 2.46 & 2.26 & 1.71 & 2.46 & 3.27 & 3.90 & 4.70 & 3.90 & 4.72 & 4.63 & 1.70 & 0.88 & 1.80 & 1.94 & 2.60 & 4.07 \\
\hline PRIV & - & 2.52 & 0.81 & 1.43 & 2.02 & 1.99 & 3.70 & 3.59 & 4.18 & 5.03 & 5.73 & 3.89 & 4.35 & 0.72 & 1.12 & 2.01 & 1.64 & 1.81 & 1.68 \\
\hline STATE & - & 4.19 & 0.63 & 0.37 & -0.14 & 1.26 & 2.29 & 2.35 & 5.34 & 2.89 & 4.19 & 4.45 & 5.09 & 1.58 & 2.49 & 1.71 & -0.47 & -0.64 & 1.31 \\
\hline
\end{tabular}


owned bank dummy variable, which takes the value of one for banks in which foreign ownership represents at least 50 percents of total share, and zero otherwise; PRIV = domestic privately owned bank dummy variable, which takes the value of one for banks in which domestic private ownership represents at least 50 percents of total share, and zero otherwise; STATE = state owned bank dummy variable, which takes the value of one for banks in which state ownership represents at least 50 percents of total share, and zero otherwise. 
TABLE 2. Factors influencing the bank risk.

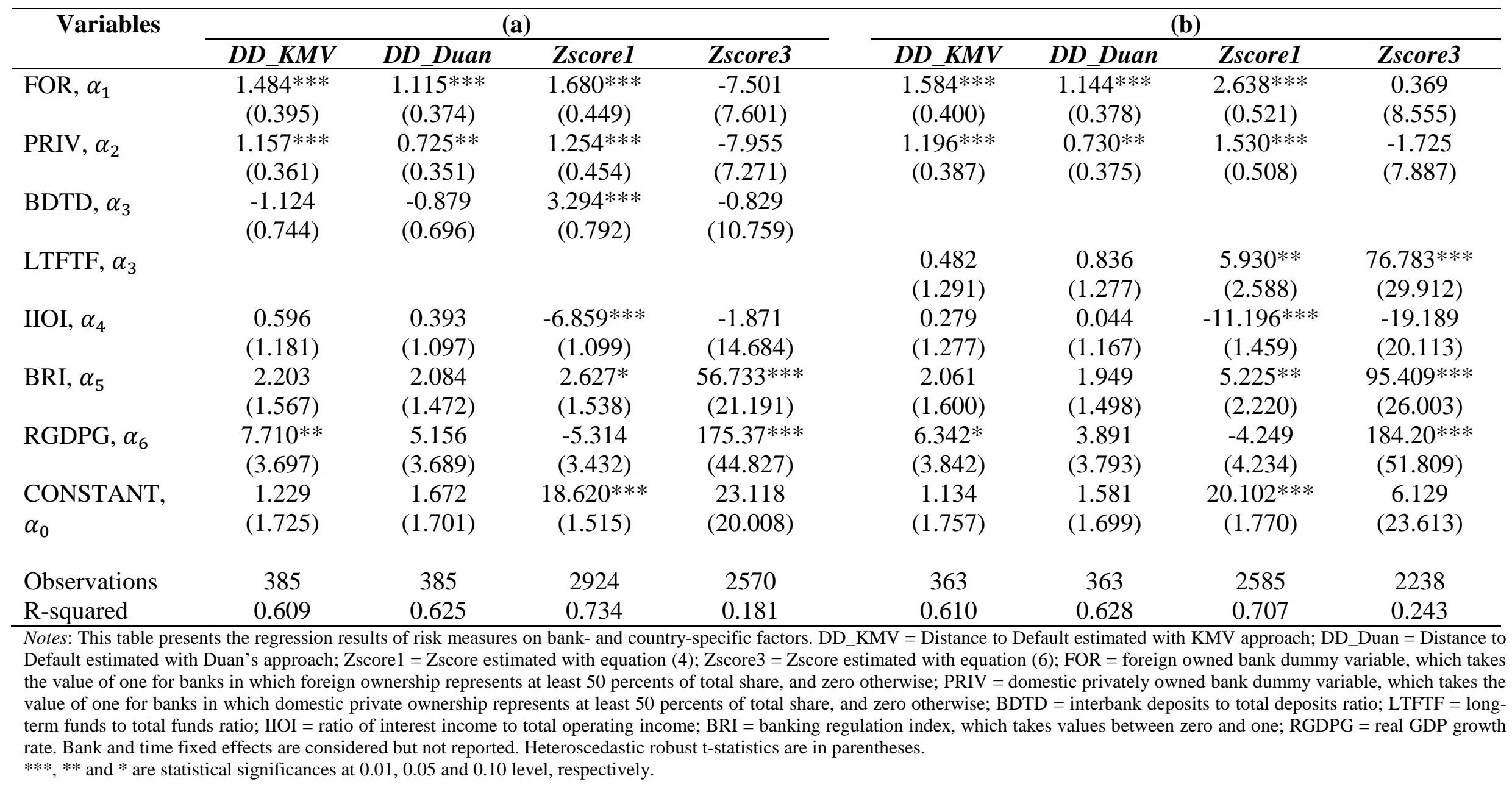


TABLE 3.Ownership implications on the effect o f bank activity funding.

\begin{tabular}{|c|c|c|c|c|c|c|c|c|}
\hline \multirow[t]{2}{*}{ Variables } & \multicolumn{4}{|c|}{ (a) } & \multicolumn{4}{|c|}{ (b) } \\
\hline & DD_KMV & DD_Duan & Zscore1 & Zscore3 & DD_KMV & DD_Duan & Zscore1 & Zscore3 \\
\hline FOR, $\alpha_{1}$ & $\begin{array}{c}1.487 * * * \\
(0.523)\end{array}$ & $\begin{array}{c}1.538^{* * *} \\
(0.486)\end{array}$ & $\begin{array}{c}3.391 * * * \\
(0.460)\end{array}$ & $\begin{array}{l}-6.450 \\
(9.043)\end{array}$ & $\begin{array}{c}1.217 * * * \\
(0.931)\end{array}$ & $\begin{array}{l}0.645^{*} \\
(0.383)\end{array}$ & $\begin{array}{c}3.257 * * * \\
(0.594)\end{array}$ & $\begin{array}{c}4.039 \\
(9.052)\end{array}$ \\
\hline PRIV, $\alpha_{2}$ & $\begin{array}{l}0.936 * \\
(0.530)\end{array}$ & $\begin{array}{c}0.619 \\
(0.501)\end{array}$ & $\begin{array}{c}2.810 * * * \\
(0.504)\end{array}$ & $\begin{array}{c}-1.201 \\
(10.258)\end{array}$ & $\begin{array}{c}0.931^{* *} \\
(0.396)\end{array}$ & $\begin{array}{c}0.367 \\
(0.376)\end{array}$ & $\begin{array}{c}2.130 * * * \\
(0.524)\end{array}$ & $\begin{array}{c}4.783 \\
(8.345)\end{array}$ \\
\hline BDTD, $\alpha_{3}$ & $\begin{array}{l}-1.416 \\
(1.662)\end{array}$ & $\begin{array}{c}0.416 \\
(1.492)\end{array}$ & $\begin{array}{c}11.764 * * * \\
(1.818)\end{array}$ & $\begin{array}{c}13.468 \\
(29.812)\end{array}$ & & & & \\
\hline BDTD*FOR, $\alpha_{4}$ & $\begin{array}{c}-0.086 \\
(1.898)\end{array}$ & $\begin{array}{c}-2.452 \\
(1.727)\end{array}$ & $\begin{array}{c}-10.399 * * * \\
(2.093)\end{array}$ & $\begin{array}{c}-11.536 \\
(31.020)\end{array}$ & & & & \\
\hline BDTD*PRIV,$\alpha_{5}$ & $\begin{array}{c}1.013 \\
(1.974)\end{array}$ & $\begin{array}{c}0.151 \\
(1.799)\end{array}$ & $\begin{array}{c}-9.681^{* * *} \\
(2.296)\end{array}$ & $\begin{array}{l}-44.219 \\
(49.118)\end{array}$ & & & & \\
\hline LTFTF, $\alpha_{3}$ & & & & & $\begin{array}{c}-9.525^{* *} \\
(4.081)\end{array}$ & $\begin{array}{c}-12.819 * * * \\
(3.729)\end{array}$ & $\begin{array}{c}16.802^{* * *} \\
(5.464)\end{array}$ & $\begin{array}{c}196.66 * * * \\
(70.72)\end{array}$ \\
\hline $\mathrm{LTFTF}^{*} \mathrm{FOR}, \alpha_{4}$ & & & & & $\begin{array}{c}10.571 * * * \\
(4.185)\end{array}$ & $\begin{array}{c}14.405^{* * *} \\
(3.858)\end{array}$ & $\begin{array}{c}-15.294^{* * *} \\
(5.565)\end{array}$ & $\begin{array}{c}-149.31^{* *} \\
(73.86)\end{array}$ \\
\hline LTFTF*PRIV,$\alpha_{5}$ & & & & & $\begin{array}{c}10.230 * * \\
(5.331)\end{array}$ & $\begin{array}{c}14.036 * * * \\
(4.776)\end{array}$ & $\begin{array}{c}-19.840 * * * \\
(5.559)\end{array}$ & $\begin{array}{c}-262.54 * * * \\
(104.60)\end{array}$ \\
\hline IIOI, $\alpha_{6}$ & $\begin{array}{c}0.658 \\
(1.180)\end{array}$ & $\begin{array}{c}0.550 \\
(1.085)\end{array}$ & $\begin{array}{c}-6.889 * * * \\
(1.091)\end{array}$ & $\begin{array}{c}-1.399 \\
(14.707)\end{array}$ & $\begin{array}{c}0.357 \\
(1.282)\end{array}$ & $\begin{array}{c}0.149 \\
(1.171)\end{array}$ & $\begin{array}{c}-10.796 * * * \\
(1.415)\end{array}$ & $\begin{array}{l}-16.008 \\
(19.520)\end{array}$ \\
\hline BRI, $\alpha_{7}$ & $\begin{array}{c}2.294 \\
(1.576)\end{array}$ & $\begin{array}{c}2.068 \\
(1.472)\end{array}$ & $\begin{array}{c}2.286 \\
(1.523)\end{array}$ & $\begin{array}{c}54.115^{* * *} \\
(21.419)\end{array}$ & $\begin{array}{c}2.275 \\
(1.592)\end{array}$ & $\begin{array}{c}2.239 \\
(1.484)\end{array}$ & $\begin{array}{c}5.263 * * * \\
(2.181)\end{array}$ & $\begin{array}{c}94.830 * * * \\
(25.531)\end{array}$ \\
\hline RGDPG, $\alpha_{8}$ & $\begin{array}{c}7.470^{* *} \\
(3.721)\end{array}$ & $\begin{array}{c}5.073 \\
(3.678)\end{array}$ & $\begin{array}{l}-5.663^{*} \\
(3.389)\end{array}$ & $\begin{array}{c}176.81^{* * *} \\
(45.147)\end{array}$ & $\begin{array}{c}6.008 \\
(3.822)\end{array}$ & $\begin{array}{c}3.434 \\
(3.758)\end{array}$ & $\begin{array}{c}-4.330 \\
(4.205)\end{array}$ & $\begin{array}{c}182.09 * * * \\
(51.763)\end{array}$ \\
\hline CONSTANT, $\alpha_{0}$ & $\begin{array}{c}1.204 \\
(1.734)\end{array}$ & $\begin{array}{c}1.285 \\
(1.697)\end{array}$ & $\begin{array}{c}17.080^{* * *} \\
(1.500)\end{array}$ & $\begin{array}{c}23.106 \\
(20.692)\end{array}$ & $\begin{array}{c}1.031 \\
(1.773)\end{array}$ & $\begin{array}{c}1.446 \\
(1.711)\end{array}$ & $\begin{array}{c}19.421^{* * *} \\
(1.767)\end{array}$ & $\begin{array}{c}1.042 \\
(23.667)\end{array}$ \\
\hline Ownership implication & & & & & & & & \\
\hline State-owned banks: $\alpha_{3}$ & -1.416 & 0.416 & $11.764^{* * *}$ & 13.468 & $-9.525^{* *}$ & $-12.819 * * *$ & $16.802^{* * *}$ & $196.66^{* * *}$ \\
\hline Foreign banks: $\alpha_{3}+\alpha_{4}$ & $-1.503 *$ & $-2.037 * *$ & 1.365 & 1.932 & 1.046 & 1.586 & 1.508 & $47.350 *$ \\
\hline Private banks: $\alpha_{3}+\alpha_{5}$ & -0.403 & 0.566 & 2.083 & -30.751 & 0.705 & 1.217 & -3.039 & -65.876 \\
\hline Observations & 385 & 385 & 2924 & 2570 & 363 & 363 & 2585 & 2238 \\
\hline R-squared & 0.609 & 0.628 & 0.739 & 0.182 & 0.614 & 0.637 & 0.710 & 0.249 \\
\hline
\end{tabular}

Notes: This table presents the regression results of ownership implications on the effect of bank activity funding. DD_KMV = Distance to Default estimated with KMV approach; DD_Duan =
Distance to Default estimated with Duan's approach; Zscore1 = Zscore estimated with equation (4); Zscore3 = Zscore estimated with equation (6); FOR = foreign owned bank dummy variable, Distance to Default estimated with Duan's approach; Zscore1 = Zscore estimated with equation (4); Zscore3 = Zscore estimated with equation (6); FOR = foreign owned bank dummy variable,
which takes the value of one for banks in which foreign ownership represents at least 50 percents of total share, and zero otherwise; PRIV = domestic privately owned bank dummy variable, which takes the value of one for banks in which domestic private ownership represents at least 50 percents of total share, and zero otherwise; BDTD = interbank deposits to total deposits ratio; LTFTF = long-term funds to total funds ratio; IIOI = ratio of interest income to total operating income; BRI = banking regulation index, which takes values between zero and one; RGDPG = real GDP growth rate. Bank and time fixed effects are considered but not reported. Heteroscedastic robust t-statistics are in parentheses. ***, ** and * are statistical significances at $0.01,0.05$ and 0.10 level, respectively. 
TABLE 4. Ownership implications on the effect of bank activity diversification.

\begin{tabular}{|c|c|c|c|c|c|c|c|c|}
\hline \multirow[t]{2}{*}{ Variables } & \multicolumn{4}{|c|}{ (a) } & \multicolumn{4}{|c|}{ (b) } \\
\hline & $D D \_K M V$ & DD_Duan & Zscore1 & Zscore3 & $D D \_K M V$ & DD_Duan & Zscore1 & Zscore3 \\
\hline \multirow[t]{2}{*}{ FOR, $\alpha_{1}$} & 2.935 & $4.489 *$ & $4.671^{* * *}$ & -10.295 & 2.321 & 3.720 & 1.578 & $-66.133^{*}$ \\
\hline & (2.638) & $(2.531)$ & (1.914) & (30.921) & $(3.570)$ & (3.351) & (3.095) & (40.733) \\
\hline \multirow[t]{2}{*}{ PRIV, $\alpha_{2}$} & 3.250 & 4.175 & $3.782 * *$ & 7.124 & 1.545 & 2.274 & -2.682 & -59.326 \\
\hline & (3.011) & $(2.821)$ & (1.990) & (32.537) & (3.908) & (3.606) & (3.140) & $(46.462)$ \\
\hline \multirow[t]{2}{*}{ BDTD, $\alpha_{3}$} & -1.160 & -0.875 & $3.320 * * *$ & -1.649 & & & & \\
\hline & $(0.748)$ & $(0.698)$ & $(0.802)$ & (10.798) & & & & \\
\hline \multirow[t]{2}{*}{ LTFTF, $\alpha_{3}$} & & & & & 0.524 & 0.951 & $5.861 * *$ & 73.827 *** \\
\hline & & & & & (1.286) & (1.270) & (2.517) & (29.044) \\
\hline \multirow{2}{*}{ IIOI, $\alpha_{4}$} & 2.563 & 4.290 & $-4.124 * *$ & 3.082 & 0.946 & 2.523 & $-13.737 * * *$ & -81.517 \\
\hline & (3.249) & (3.099) & $(1.950)$ & (37.990) & (4.348) & (4.058) & (3.680) & (53.086) \\
\hline \multirow[t]{2}{*}{ IIOI*FOR, $\alpha_{5}$} & -1.772 & -4.102 & $-3.898 *$ & 3.684 & -0.883 & -3.089 & 1.332 & 86.390 \\
\hline & (3.211) & (3.062) & $(2.407)$ & (40.087) & (4.297) & (4.015) & (4.058) & (54.434) \\
\hline \multirow[t]{2}{*}{ IIOI*PRIV,$\alpha_{6}$} & -2.583 & -4.217 & -3.254 & -20.894 & -0.404 & -1.818 & 5.622 & 74.653 \\
\hline & (3.742) & (3.497) & (2.535) & $(42.084)$ & $(4.784)$ & (4.403) & (4.059) & (61.630) \\
\hline \multirow[t]{2}{*}{ BRI, $\alpha_{7}$} & 1.993 & 1.633 & 2.437 & $57.133 * * *$ & 1.999 & 1.718 & $5.075 * *$ & $96.617 * * *$ \\
\hline & $(1.625)$ & $(1.528)$ & $(1.567)$ & $(21.131)$ & $(1.650)$ & $(1.552)$ & $(2.234)$ & $(25.952)$ \\
\hline \multirow[t]{2}{*}{ RGDPG, $\alpha_{8}$} & $7.533^{* *}$ & 5.460 & $-5.622 *$ & $174.45 * * *$ & $6.610^{*}$ & 4.697 & -3.718 & $185.67 * * *$ \\
\hline & $(3.884)$ & (3.837) & (3.459) & $(44.881)$ & (4.039) & (3.961) & (4.295) & (51.928) \\
\hline \multirow{2}{*}{ CONSTANT, $\alpha_{0}$} & -0.305 & -1.317 & $16.631^{* * *}$ & 19.158 & 0.600 & -0.401 & $22.094 * * *$ & 53.579 \\
\hline & $(0.915)$ & $(2.770)$ & (1.877) & (33.469) & (3.714) & (3.503) & (2.749) & (39.284) \\
\hline \multicolumn{9}{|l|}{ Ownership implication } \\
\hline State-owned banks: $\alpha_{4}$ & 2.563 & 4.290 & $-4.124 * *$ & 3.082 & 0.946 & 2.523 & $-13.737 * * *$ & -81.517 \\
\hline Foreign banks: $\alpha_{4}+\alpha_{5}$ & 0.791 & 0.188 & $-8.023 * * *$ & 6.767 & 0.063 & -0.567 & $-12.405^{* * *}$ & 4.872 \\
\hline Private banks: $\alpha_{4}+\alpha_{6}$ & -0.020 & 0.073 & $-7.379 * * *$ & -17.812 & 0.541 & 0.705 & $-8.115^{* * *}$ & -6.865 \\
\hline Observations & 385 & 385 & 2924 & 2570 & 363 & 363 & 2585 & 2238 \\
\hline R-squared & 0.609 & 0.627 & 0.735 & 0.182 & 0.610 & 0.629 & 0.707 & 0.244 \\
\hline
\end{tabular}

Notes: This table presents the regression results of ownership implications on the effect of bank activity diversification. DD_KMV = Distance to Default estimated with KMV approach; DD Duan = Distance to Default estimated with Duan's approach; Zscore1 = Zscore estimated with equation (4); Zscore3 = Zscore estimated with equation (6); FOR = foreign owned bank dummy variable, which takes the value of one for banks in which foreign ownership represents at least 50 percents of total share, and zero otherwise; PRIV = domestic privately owned bank dummy variable, which takes the value of one for banks in which domestic private ownership represents at least 50 percents of total share, and zero otherwise; BDTD = interbank deposits to total deposits ratio; LTFTF = long-term funds to total funds ratio; IIOI = ratio of interest income to total operating income; BRI = banking regulation index, which takes values between zero and one; RGDPG = real GDP growth rate. Bank and time fixed effects are considered but not reported. Heteroscedastic robust t-statistics are in parentheses.

***, ** and * are statistical significances at $0.01,0.05$ and 0.10 level, respectively. 
TABLE 5. Ownership implications on the effect of banking regulation.

\begin{tabular}{|c|c|c|c|c|c|c|c|c|}
\hline \multirow[t]{2}{*}{ Variables } & \multicolumn{4}{|c|}{ (a) } & \multicolumn{4}{|c|}{ (b) } \\
\hline & DD_KMV & DD_Duan & Zscore1 & Zscore3 & DD_KMV & DD_Duan & Zscore1 & Zscore3 \\
\hline FOR, $\alpha_{1}$ & $\begin{array}{c}-3.344^{* * *} \\
(1.302)\end{array}$ & $\begin{array}{c}-3.210 * * * \\
(1.277)\end{array}$ & $\begin{array}{c}0.914 \\
(2.159)\end{array}$ & $\begin{array}{c}19.126 \\
(31.513)\end{array}$ & $\begin{array}{c}-5.894 * * * \\
(1.568)\end{array}$ & $\begin{array}{c}-5.823 * * * \\
(1.466)\end{array}$ & $\begin{array}{c}2.123 \\
(3.009)\end{array}$ & $\begin{array}{c}57.535 \\
(38.617)\end{array}$ \\
\hline PRIV, $\alpha_{2}$ & $\begin{array}{l}-1.027 \\
(1.864)\end{array}$ & $\begin{array}{c}-0.916 \\
(1.838)\end{array}$ & $\begin{array}{l}3.684^{*} \\
(2.201)\end{array}$ & $\begin{array}{c}40.185 \\
(32.604)\end{array}$ & $\begin{array}{c}-4.272 * * \\
(2.041)\end{array}$ & $\begin{array}{c}-3.972 * * \\
(1.955)\end{array}$ & $\begin{array}{c}5.785^{* *} \\
(3.062)\end{array}$ & $\begin{array}{c}80.261^{* *} \\
(39.713)\end{array}$ \\
\hline $\mathrm{BDTD}, \alpha_{3}$ & $\begin{array}{l}-1.252 * \\
(0.743)\end{array}$ & $\begin{array}{l}-1.018 \\
(0.694)\end{array}$ & $\begin{array}{c}3.163 * * * \\
(0.802)\end{array}$ & $\begin{array}{c}-1.985 \\
(10.933)\end{array}$ & & & & \\
\hline LTFTF, $\alpha_{3}$ & & & & & $\begin{array}{c}0.598 \\
(1.307)\end{array}$ & $\begin{array}{c}0.915 \\
(1.285)\end{array}$ & $\begin{array}{c}5.814 * * \\
(2.592)\end{array}$ & $\begin{array}{c}74.984 * * * \\
(29.909)\end{array}$ \\
\hline IIOI, $\alpha_{4}$ & $\begin{array}{c}1.017 \\
(1.205)\end{array}$ & $\begin{array}{c}0.817 \\
(1.106)\end{array}$ & $\begin{array}{c}-6.782 * * * \\
(1.105)\end{array}$ & $\begin{array}{c}-2.683 \\
(14.705)\end{array}$ & $\begin{array}{c}0.447 \\
(1.291)\end{array}$ & $\begin{array}{c}0.251 \\
(1.169)\end{array}$ & $\begin{array}{c}-11.140^{* * * *} \\
(1.464)\end{array}$ & $\begin{array}{l}-20.412 \\
(20.251)\end{array}$ \\
\hline BRI, $\alpha_{5}$ & $\begin{array}{c}-5.665 * * \\
(2.744)\end{array}$ & $\begin{array}{l}-4.859 * \\
(2.672)\end{array}$ & $\begin{array}{c}3.494 \\
(4.057)\end{array}$ & $\begin{array}{l}118.42^{* *} \\
(61.078)\end{array}$ & $\begin{array}{c}-11.052^{* * *} \\
(3.214)\end{array}$ & $\begin{array}{c}-10.151^{* * *} \\
(2.978)\end{array}$ & $\begin{array}{c}7.794 \\
(6.201)\end{array}$ & $\begin{array}{c}216.97 * * * \\
(77.966)\end{array}$ \\
\hline $\mathrm{BRI} * \mathrm{FOR}, \alpha_{6}$ & $\begin{array}{c}10.381^{* * * *} \\
(2.701)\end{array}$ & $\begin{array}{c}9.320 * * * \\
(2.658)\end{array}$ & $\begin{array}{c}1.716 \\
(4.144)\end{array}$ & $\begin{array}{l}-54.179 \\
(60.004)\end{array}$ & $\begin{array}{c}15.644^{* * *} \\
(3.237)\end{array}$ & $\begin{array}{c}14.598^{* * *} \\
(3.029)\end{array}$ & $\begin{array}{c}1.343 \\
(5.781)\end{array}$ & $\begin{array}{l}-117.07 \\
(74.247)\end{array}$ \\
\hline $\mathrm{BRI} * \mathrm{PRIV}, \alpha_{7}$ & $\begin{array}{c}4.820 \\
(3.881)\end{array}$ & $\begin{array}{c}3.664 \\
(3.833)\end{array}$ & $\begin{array}{l}-5.331 \\
(4.436)\end{array}$ & $\begin{array}{l}-103.39 * \\
(65.604)\end{array}$ & $\begin{array}{c}11.409^{* * *} \\
(4.255)\end{array}$ & $\begin{array}{c}9.806 * * * \\
(4.080)\end{array}$ & $\begin{array}{l}-9.237 \\
(6.132)\end{array}$ & $\begin{array}{c}-175.30 * * \\
(80.697)\end{array}$ \\
\hline RGDPG, $\alpha_{8}$ & $\begin{array}{c}5.433 \\
(3.763)\end{array}$ & $\begin{array}{c}2.954 \\
(3.763)\end{array}$ & $\begin{array}{l}-5.775^{*} \\
(3.405)\end{array}$ & $\begin{array}{c}170.73 * * * \\
(44.797)\end{array}$ & $\begin{array}{c}3.412 \\
(3.884)\end{array}$ & $\begin{array}{c}1.035 \\
(3.845)\end{array}$ & $\begin{array}{l}-4.993 \\
(4.243)\end{array}$ & $\begin{array}{c}183.25^{* * *} \\
(51.887)\end{array}$ \\
\hline CONSTANT, $\alpha_{0}$ & $\begin{array}{l}4.840 * * \\
(2.063)\end{array}$ & $\begin{array}{c}4.828 * * \\
(2.027)\end{array}$ & $\begin{array}{c}18.274 * * * \\
(2.515)\end{array}$ & $\begin{array}{c}-6.030 \\
(35.443)\end{array}$ & $\begin{array}{c}7.668 * * * \\
(2.263)\end{array}$ & $\begin{array}{c}7.592 \\
(2.138)\end{array}$ & $\begin{array}{c}18.961^{* * *} \\
(3.515)\end{array}$ & $\begin{array}{l}-51.619 \\
(41.553)\end{array}$ \\
\hline Ownership implication & & & & & & & & \\
\hline State-owned banks: $\alpha_{5}$ & $-5.665 * *$ & $-4.859 *$ & 3.494 & $118.42^{* *}$ & $-11.052^{* * *}$ & $-10.151^{* * *}$ & 7.794 & $216.97 * * *$ \\
\hline Foreign banks: $\alpha_{5}+\alpha_{6}$ & $4.716^{* * * *}$ & $4.460 * * *$ & $5.210 * * *$ & $64.246 * * *$ & $4.592^{* * *}$ & $4.447 * * *$ & $9.137 * * *$ & $99.899 * * *$ \\
\hline Private banks: $\alpha_{5}+\alpha_{7}$ & -0.845 & -1.195 & -1.837 & 15.031 & 0.358 & -0.345 & -1.444 & 41.668 \\
\hline Observations & 385 & 385 & 2924 & 2570 & 363 & 363 & 2585 & 2238 \\
\hline R-squared & 0.621 & 0.636 & 0.735 & 0.182 & 0.628 & 0.645 & 0.707 & 0.244 \\
\hline $\begin{array}{l}\text { Note: This table presents } t \\
\text { Distance to Default estimat } \\
\text { which takes the value of or } \\
\text { which takes the value of on } \\
\text { LTFTF = long-term funds t } \\
\text { GDP growth rate. Bank and } \\
* * *, * * \text { and * are statistical }\end{array}$ & $\begin{array}{l}\text { gression resu } \\
\text { ith Duan's ap } \\
\text { r banks in wh } \\
\text { r banks in wh } \\
\text { al funds ratio; } \\
\text { e fixed effects } \\
\text { ificances at } 0\end{array}$ & $\begin{array}{l}\text { ownership im } \\
\text {; Zscore } 1=Z \\
\text { reign ownersh } \\
\text { nestic private } \\
\text { ratio of inter } \\
\text { nsidered but r } \\
5 \text { and } 0.10 \text { le }\end{array}$ & $\begin{array}{l}\text { ns on the eff } \\
\text { stimated witl } \\
\text { esents at leas } \\
\text { hip represen } \\
\text { me to total o } \\
\text { rted. Heteros } \\
\text { pectively. }\end{array}$ & $\begin{array}{l}\text { banking regul } \\
\text { ion (4); Zscor } \\
\text { arcents of tota } \\
\text { ast } 50 \text { percent } \\
\text { g income; BR } \\
\text { ic robust t-stat }\end{array}$ & $\begin{array}{l}\text { D_KMV = Dis } \\
\text { ore estimated v } \\
\text { ind zero otherv } \\
\text { share, and zer } \\
\text { ng regulation i } \\
\text { in parentheses }\end{array}$ & $\begin{array}{l}\text { to Default est } \\
\text { quation (6); FO } \\
\text { RIV = domest } \\
\text { rwise; BDTD } \\
\text { which takes va }\end{array}$ & $\begin{array}{l}\text { with KMV } \\
\text { oreign owned } \\
\text { vately owned } \\
\text { bank deposits } \\
\text { etween zero a }\end{array}$ & $\begin{array}{l}\text { ch; DD_Duan } \\
\text { lummy variab } \\
\text { lummy variab } \\
\text { al deposits rat } \\
\text {; RGDPG = r }\end{array}$ \\
\hline
\end{tabular}


TABLE B1. Factors influencing the bank risk, with barriers to entry index.

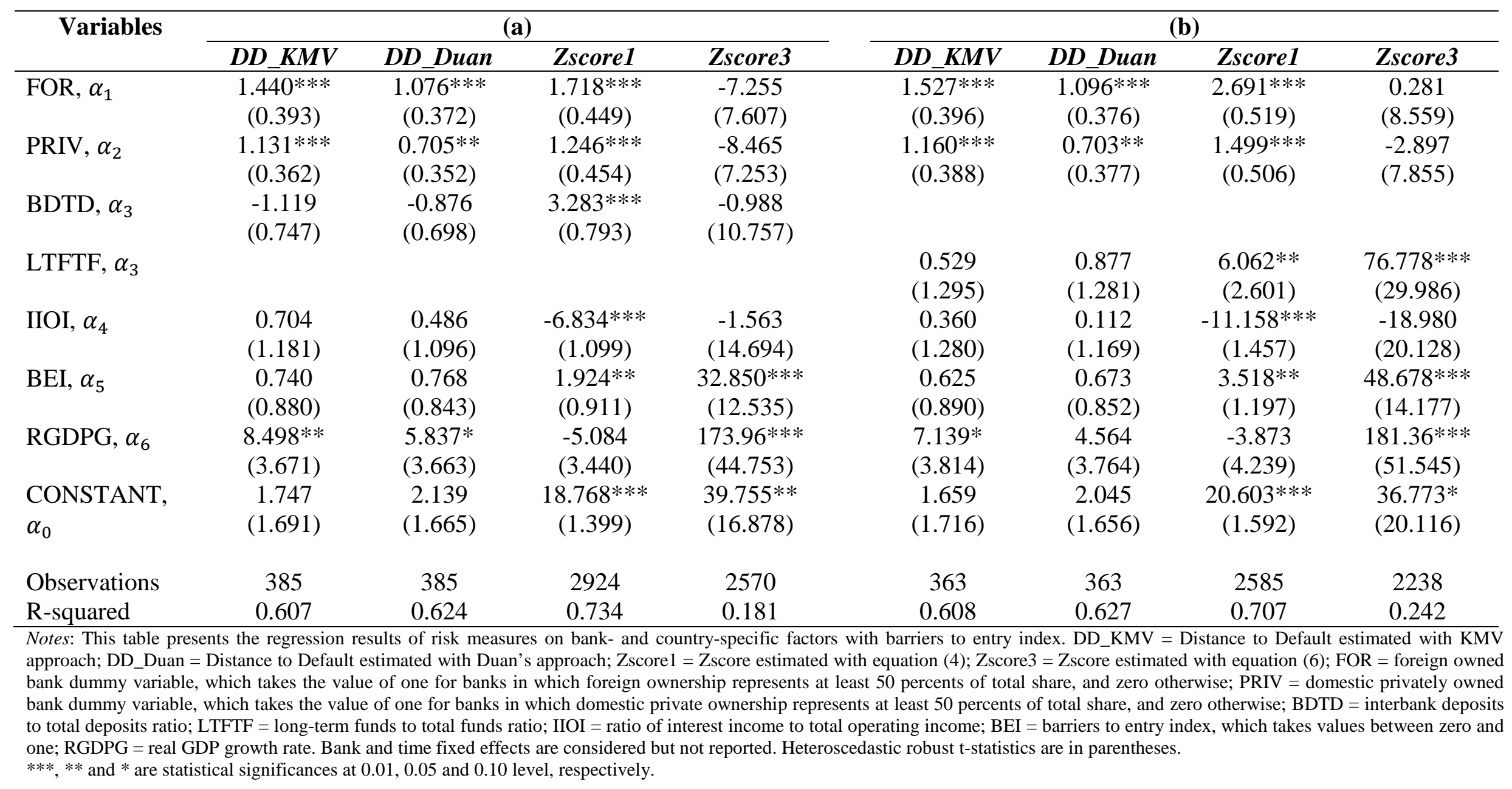


TABLE B2. Factors influencing the bank risk, with stability regulation index.

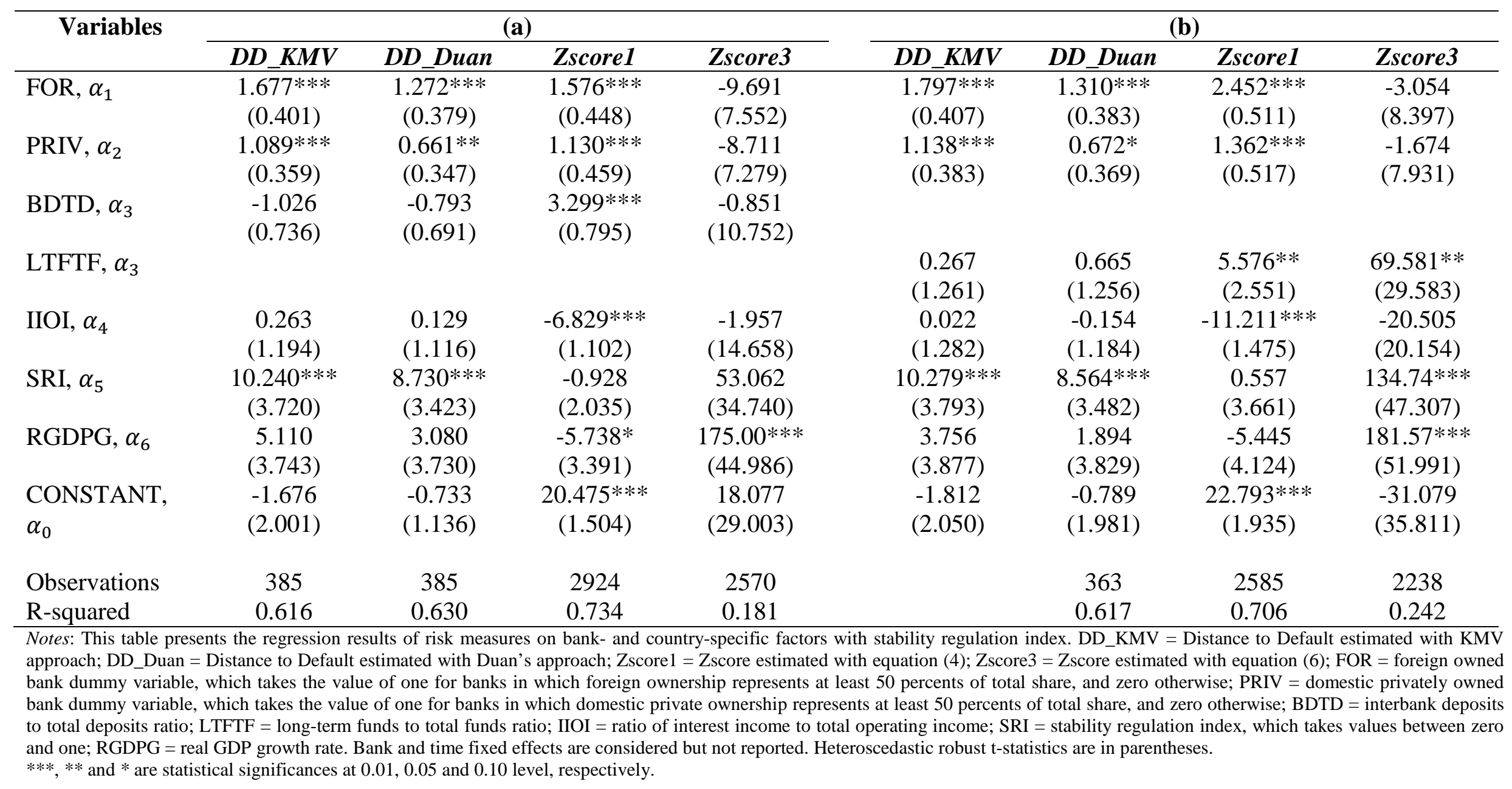




\section{ReCent LAREFI Working PAPers}

For earlier LAREFI Working Papers, please go to http://lare-efi.u-bordeaux4.fr

\section{All Discussion Papers can be downloaded free of charge}

CR16-EFI08 Lapteacru, I., "Murphy-Topel adjustment of the variance-covariance matrix of a two-step panel data model : Evidence from competition-fragility nexus in banking"

CR16-EFI07 Faure, P-H., "Le bitcoin peut-il être assimilé à une monnaie ? Un examen à partir des différentes grilles de lecture de la science économique"

CR16-EFI06 Lapteacru, I., "Convergence of bank competition in Central and Eastern European countries : Does ownership matter ?"

CR16-EFI05 Lapteacru, I., "On the consistency of the Z-score to measure the bank risk"

CR16-EFI04 Lapteacru, I., "Income and funding structures, banking regulation and bank risktaking : The role of ownership in Central and Eastern European banks"

CR16-EFI03 Humblot, T., "Distance et accès au crédit sous Bâle III"

CR16-EFI02 Berthoumieu, J. and V. Lamani, "Vertical Differentiation, Uncertainty, Product R\&D and Policy Instruments in a North-South Duopoly"

CR16-EFI01 Raffestin, L., "Foreign exchange investment rules and endogenous currency crashes"

CR15-EFI05 Berthoumieu,J., "Technology Diffusion via Patent Collaborations : The Case of European Integration"

CR15-EFI04 Bouet, A. and A-G. Vaubourg, "Financial Constraints and International Trade with Endogenous Mode of Competition"

CR15-EFI03 Lahet, D. and A-G. Vaubourg, "Banks' shareholding in multilateral trading facilities : A two-sided market perspective"

CR15-EFI02 Berthoumieu, J., "Policy Instruments, Patents and International Technology Diffusion in a North-South Duopoly"

CR15-EFI01 Dupuy, L., "International trade and structural change : a dynamic model of weak sustainability" 